Niğde Ömer Halisdemir Üniversitesi Mühendislik Bilimleri Dergisi
Niğde Ömer Halisdemir University Journal of Engineering Sciences

\title{
Mevcut okul türü bir binanın deprem performansının 2007 ve 2018 deprem yönetmeliklerine göre değerlendirilmesi
}

\section{An evaluation on seismic performance of an existing school building according to the 2007 and 2018 Turkish Seismic Codes}

\author{
Mehmet Yalın1(D), Hakan Ulutaş²,* (iD) \\ ${ }^{1}$ Inşaat Yüksek Mühendisi, 07190, Antalya, Türkiye \\ ${ }^{2}$ Burdur Mehmet Akif Ersoy Üniversitesi, İnşaat Mühendisliği Bölümü, 15030, Burdur, Türkiye
}

\begin{abstract}
Özet
$\mathrm{Bu}$ çalışmada, boyuna donatıları nervürsüz (düz) donatı çeliği ile düzenlenmiş, perdeli çerçeveli taşıyıcı sisteme sahip mevcut okul türü bir binanın Deprem Bölgelerinde Yapılacak Binalar Hakkında Yönetmelik (DBYBHY2007) ve Türkiye Bina Deprem Yönetmeliği (TBDY2018)'nin her ikisine göre de deprem performans1 belirlenmiş elde edilen sonuçlar kıyaslanmıştır. TBDY (2018)'e göre betonarme elemanların boyuna donatıları nervürsüz (düz) donatı çeliği ile düzenlenmişse, donatı çeliği birim şekildeğiştirme talebi ve plastik dönme talebi 1,5 ile çarpılarak arttırılması gerekmektedir. DBYBHY (2007)'de bu koşul bulunmadığından iki yönetmeliği kıyaslamak için nervürsüz donatıya sahip mevcut okul türü bir binanın seçilmesi yönetmelikleri kıyaslamak adına daha uygun olacağı düşünülmüştür. Analizler doğrusal elastik olmayan değerlendirme yöntemi kullanılarak yapılmıştır. İki yönetmeliğin performans sonuçları kıyaslandığında yönetmelikler arasındaki uyumsuzluğun 50 yılda aşılma olasıllı̆ $\% 2$ olan depremler için olduğu tespit edilmiştir. 50 yılda aşılma olasıllı̆̆ $\% 2$ olan depremler için binanın Y doğrultusu DBYBHY (2007)'e göre hedef performans seviyesini sağlıyorken, TBDY 2018'e göre hedef performans seviyesini sağlayamadığı belirlenmiştir.
\end{abstract}

Anahtar kelimeler: Performans analizi, Doğrusal elastik olmayan yöntem, DBYBHY 2007 ve TBDY 2018 yönetmeliklerinin kıyaslanması

\section{Giriş}

Ülkemizde, binaları depreme karşı güvenli inşa etmek amacıyla ilk olarak 1940 yılında "Zelzele Mintıkalarında Yapılacak İnşaata Ait İtalyan Yapı Talimatnamesi" hazırlanmıştır. Zaman içinde yapılan bilimsel çalışmalar ve teknolojik imkânların çoğalması ile mevcut yönetmeliklerin eksiklikleri görülmüş ve bu yönetmeliklerin güncellenme ihtiyacı doğmuştur. Ülkemizde, 2018 yılına kadar dokuz kez değişen deprem yönetmeliği son olarak Türkiye Bina Deprem Yönetmeliği (TBDY, 2018) [1] adıyla 2019 yılında yürürlüğe girmiştir.

Mevcut binaların performanslarının belirlenmesi konusu ilk kez Deprem Bölgelerinde Yapılacak Binalar Hakkında

\begin{abstract}
In this study, the seismic performance of an existing schooltype building with a wall-framed system with longitudinal reinforcements arranged with non-ribbed reinforcement steel was determined according to both Turkish Seismic Code (TSC-2007) and Turkish Seismic Code (TSC-2018) and the two codes were compared based on the results. According to the TSC (2018), if the longitudinal reinforcement of the reinforced concrete elements is arranged with non-ribbed reinforcement steel, this steel should be multiplied by the strain request and the plastic rotation request by 1.5 needs to be increased. Since there was no such requirement in TSC (2007), it was thought that it would be more appropriate to choose an existing schooltype building with non-ribbed reinforcement to compare the two regulations. Analyses were carried out using the non-linear elastic evaluation method. The comparison between the performance results of the two regulations illustrated that the incompatibility between the regulations is for earthquakes with a $2 \%$ probability of exceeding in 50 years. It has been determined that while the Y direction of the building has achieved the target performance level according to TSC (2007) for earthquakes with a probability of exceeding $2 \%$ in 50 years, it cannot achieve the target performance level according to TSC (2018)
\end{abstract}

Keywords: Performance analysis, Nonlinear method, Comparison of TSC 2007 and TSC 2018 regulations

Yönetmelik 2007 (DBYBHY 2007) [2]'de yer almıştır. Mevcut bina sistemlerinin deprem performanslarının belirlenmesi konusu TBDY (2018) [1]'de de yer almış fakat DBYBHY (2007) [2]'e göre değerlendirme esaslarında bazı değişikliklere gidilmiştir. Literatürde yönetmelikte meydana gelen değişikliğin bina deprem davranışı üzerindeki etkisini araştırmak için çalışmalar yayınlanmaya başlanmıştır. Karaca vd. [3], Niğde İl merkezinde bulunan ve TBDY (2018) [1]'e göre tasarlanan 5 adet betonarme binayı 2007 ve 2018 deprem yönetmeliklerine göre yapısal tasarım bağlamda karşılaştırmıştır. Yapılan analizler sonucu 2018 deprem yönetmeliğine göre tasarlanacak bir binada daha fazla beton kullanılması gerekeceği, ancak donatı miktarında

\footnotetext{
* Sorumlu yazar / Corresponding author, e-posta / e-mail: hakannulutas@gmail.com (H. Ulutaş)

Geliş / Recieved: 14.03.2021 Kabul / Accepted: 21.04.2021 Yayımlanma / Published: 27.07.2021

doi: $10.28948 /$ ngmuh. 911167
} 
genelde azalma eğilimi olduğunu gözlemlenmiştir. Severcan vd. [4], 8 katlı mevcut betonarme bir binanın deprem performansinı DBYBHY (2007) [2] ve Eurocode 8 [5]'e göre statik itme analizi kullanarak belirlemiştir. Yapılan değerlendirme sonucu eleman performans düzeylerinin özellikle düşey taşıyıcı elemanlarda birbirine yakın olduğu ancak DBYBHY (2007) [2]'nin Eurocode 8 [5]'e göre daha güvenli tarafta kaldığ 1 görülmüştür. Ulutaş [6], 2007 ve 2018 deprem yönetmeliklerini kesit hasar sınırları bakımından kıyaslamıştır. Yapılan inceleme sonucu 2018 deprem yönetmeliğinin deprem güvenliği açsından 2007 deprem yönetmeliğine göre daha güvenli tarafta kaldığı sonucuna varmıştır. Ünsal vd. [7], yapı yüksekliğinin taban kesme kuvveti ve tepe yerdeğiştirmesi üzerindeki etkisini DBYBHY (2007) [2] ve TBDY (2018) [1] yönetmeliklerine göre incelemişlerdir. İki yönetmeliğe göre elde edilen taban kesme kuvveti değerlerinin yakın olması halinde, TBDY (2018) [1] esas alınarak elde edilen maksimum yerdeğiştirmesinin DBYBHY (2007) [2] esas alınarak elde edilen maksimum yerdeğiştirmesi değerlerinden çok daha büyük olduğunu gözlemlemişlerdir. Dalyan ve Şahin [8], mevcut 5 katlı betonarme konut türü bir binanın doğrusal olmayan artımsal itme analizi yöntemiyle, DBYBHY (2007) [2] ve TBDY (2018) [1] yöntemlerinin her ikisine göre de taşıyıcı sisteminin performans analizi yapılmış ve elde edilen sonuçlar karşılaştırılarak irdelenmiştir. Sarı [9], mevcut konut türü bir binanın TBDY (2018) [1] ve DBYBHY (2007) [2] yönetmeliklerine göre deprem performansını statik itme analiziyle belirlemiştir. İncelenen konut türü binanın her iki yönetmeliğe göre de hedef performans seviyesini sağladığını belirlemiştir. Ayaz [10], DBYBHY (2007) [2]'e göre güçlendirilmiş bir binanın, TBDY (2018) [1]'e göre doğrusal olmayan davranışını incelemiştir. Binanın DD-1 ve DD-3 deprem düzeylerine göre performans analizlerini yaparak TBDY (2018) [1]'in şartlarını sağlandığını tespit etmiştir. Eldemir [11] yapmış olduğu tez çalışmasında, DBYBHY (2007) [2] ve TBDY (2018) [1] yönetmeliklerini mevcut yapıların sismik davranış özellikleri açısından karşılaştırmıştır. Yapılan çalışma sonucu her iki yönetmelikle elde edilen çatı katı ötelenme oranları, deplasman profilleri ve göreli kat ötelenme oranlarında farklılıklar olduğunu belirlemiştir. Nemutlu [12] yaptığı tez çalışmasında, TBDY (2018) [1] ve DBYBHY (2007) [2] yönetmeliklerini deprem hesapları açısından Amerikan deprem yönetmeliği (ASCE 7-16) [13] ile karşılaştırmıştır. Elci vd. [14], 2007 ve 2018 deprem yönetmeliklerini betonarme kolonların deprem performansının değerlendirilmesi bakımından kıyaslamışlardır. Yönetmeliklerin kıyaslanması için deneysel ve teorik bir çalışma yapmışlardır. Çalışma sonucunda, 2018 deprem yönetmeliğinin 2007 deprem yönetmeliğine göre daha güvenli tarafta kalan deformasyon limitleri verdiğini belirlemişlerdir.

Bu çalışmada, boyuna donatıları nervürsüz (düz) donatı çeliği ile düzenlenmiş, perdeli çerçeveli taşıyıcı sisteme sahip mevcut okul türü bir binanın DBYBHY (2007) [2] ve TBDY (2018) [1] deprem yönetmeliklerinin her ikisine göre de deprem performansı belirlenmiş iki yönetmeliğe göre elde edilen bu sonuçlar kıyaslanmıştır. Seçilen okul binasının boyuna donatılarının nervürsüz (düz) donatı çeliği ile düzenlenmiş olmasına özellikle dikkat edilmiştir. Çünkü TBDY (2018) [1] yönetmeliğine göre betonarme elemanların boyuna donatıları nervürsüz (düz) donatı çeliği ile düzenlenmişse, donatı çeliği birim şekildeğiştirme talebi ve plastik dönme talebi 1,5 ile çarpılarak arttırılması gerekmektedir. DBYBHY (2007) [2]'de bu koşul bulunmadığından iki yönetmeliği kıyaslamak için nervürsüz donatıya sahip mevcut okul türü bir binanın seçilmesi yönetmelikleri kıyaslamak adına daha uygun olacağı düşünülmüştür. Analizler doğrusal elastik olmayan değerlendirme yöntemi kullanılarak yapılmıştır. Kesitlerin moment eğrilik analizleri ve plastik mafsal özelikleri ile binanın itme analizleri için SAP 2000 [15] programından faydalanılmıştır.

\section{Materyal ve metot}

Mevcut binaların deprem güvenliğinin belirlenmesi için DBYBHY (2007) [2] ve TBDY (2018) [1]'de doğrusal elastik ve doğrusal elastik olmayan değerlendirme yöntemi olmak üzere iki tip yöntemden bahsedilmektedir. Belirtilen bu iki yöntemden doğrusal olan değerlendirme yönteminde dayanım esaslı yaklaşım ile çözümleme yapılırken, doğrusal olmayan değerlendirme yönteminde, şekildeğiştirme ve yer değiştirme esaslı yaklaşım ile çözümleme yapılmaktadır.

Bu çalışmada, 2007 deprem yönetmeliğine göre yapılan çözümler doğrusal olmayan değerlendirme yöntemlerinden artımsal eşdeğer deprem yükü yöntemiyle, 2018 deprem yönetmeliğine göre yapılan çözümler ise artımsal eşdeğer deprem yükünün 2018 deprem yönetmeliğinde karşılığg olan tek modlu itme yöntemi ile yapılmıştır.

\subsection{Kesit hasar sinırlarl, hasar durumlart ve hasar bölgeleri}

\subsubsection{DBYBHY 2007'e göre kesit hasar sinırlarl, hasar durumlarl ve hasar bölgeleri}

DBYBHY (2007) [2]'de sünek elemanlar için kesit düzeyinde Minimum Hasar Sınırı (MN), Güvenlik Sınırı (GV) ve Göçme Sınırı (GÇ) olmak üzere üç hasar durumu ve hasar sınırı tanımlanmıştır. Doğrusal elastik olmayan analiz sonucu taşıyıcı elemanlarda meydana gelen şekil değiştirmelerin Tablo 1'de verilen birim şekildeğiştirme üst sınırları ile kıyaslanmasıyla kesitin hasarı belirlenmiş olur.

Tablo 1. Beton ve donatı şekildeğiştirme üst sınırları

\begin{tabular}{|c|c|c|}
\hline $\begin{array}{ll}\text { Kesit } & \text { hasar } \\
\text { sinırı } & \end{array}$ & $\begin{array}{l}\text { Beton şekildeğiştirme } \\
\text { üst sinırları }\end{array}$ & $\begin{array}{l}\text { Donatı çeliği } \\
\text { şekildeğiştirme } \\
\text { üst sınırları }\end{array}$ \\
\hline MN & $\left(\varepsilon_{\mathrm{cu}}\right)=0.0035$ & $\left(\varepsilon_{\mathrm{s}}\right)=0.010$ \\
\hline GV & $\begin{array}{c}\left(\varepsilon_{\mathrm{cg}}\right)=0.0035+0.01\left(\rho_{\mathrm{s}} / \rho_{\mathrm{sm}}\right) \leq \\
0.0135\end{array}$ & $\left(\varepsilon_{\mathrm{s}}\right)=0.040$ \\
\hline GÇ & $\begin{array}{c}\left(\varepsilon_{\mathrm{cg}}\right)=0.004+0.014\left(\rho_{\mathrm{s}} / \rho_{\mathrm{sm}}\right) \leq \\
0.018\end{array}$ & $\left(\varepsilon_{\mathrm{s}}\right)=0.060$ \\
\hline
\end{tabular}

Tablo 1'de geçen $\varepsilon_{\mathrm{cg}}$, etriyenin en dış lifindeki beton basınç birim şekildeğiştirmesini; $\varepsilon_{\mathrm{cu}}$, kesitin en dış lifindeki beton basınç birim şekildeğiştirmesini; $\varepsilon_{\mathrm{s}}$, donatı çeliği birim şekildeğiştirmesini; $\rho_{\mathrm{s}}$, kesitte bulunan enine donatının hacimsel oranını; $\rho_{\mathrm{sm}}$ ise DBYBHY (2007) [2]'e göre kesitte 
bulunması gereken enine donatının hacimsel oranını ifade etmektedir.

Elemanın kritik kesitlerinin hasarına bakılarak hangi hasar bölgesinde kaldığına karar verilir. DBYBHY (2007) [2]'de verilen hasar sınırları ve hasar bölgeleri Şekil 1'de gösterilmiştir.

\section{İç Kuvvet}

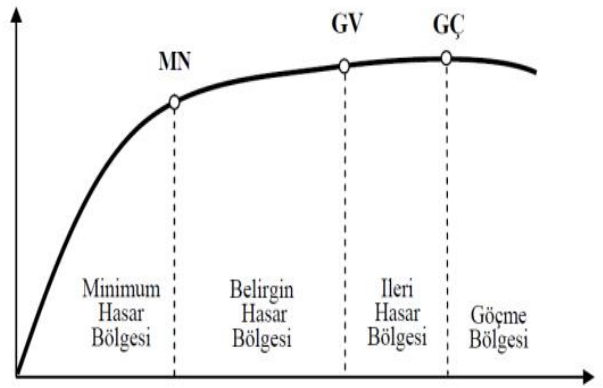

Sekildeğiștirme

Şekil 1. DBYBHY (2007) [2]'de verilen kesit hasar sınırları ve hasar bölgeleri

\subsubsection{TBDY 2018'e göre kesit hasar sinırlarl, hasar durumlarl ve hasar bölgeleri}

TBDY (2018) [1]'de sünek elemanlar için kesit düzeyinde Sınırlı Hasar $(\mathrm{SH})$, Kontrollü Hasar $(\mathrm{KH})$ ve Göçme Öncesi Hasar (GÖ) olmak üzere üç hasar durumu ve hasar sınırı tanımlanmıştır. Doğrusal elastik olmayan analiz sonucu taşıyıcı elemanlarda meydana gelen plastik dönmelerin Tablo 2'de yığılı plastik davranış modeli için verilen plastik dönme üst sınırları ile kıyaslanmasıyla kesitin hasarı belirlenmiş olur.

Tablo 2. Plastik dönme üst sınırları

\begin{tabular}{cc}
\hline $\begin{array}{c}\text { Hasar } \\
\text { sinırı }\end{array}$ & Plastik dönme üst sinırları $\left(\theta_{p}\right)$ \\
\hline GÖ & $\theta_{\mathrm{p}}^{(\mathrm{GÖ})}=\frac{2}{3}\left(\left(\phi_{\mathrm{u}}-\phi_{\mathrm{y}}\right) L_{\mathrm{p}}\left(1-0.5 \frac{L_{\mathrm{p}}}{L_{\mathrm{s}}}\right)+4.5 \phi_{\mathrm{u}} d_{\mathrm{b}}\right)$ \\
$\mathrm{KH}$ & $\theta_{\mathrm{p}}^{(\mathrm{KH})}=0.75 \theta_{\mathrm{p}}^{(\mathrm{GÖ})}$ \\
$\mathrm{SH}$ & $\theta_{\mathrm{p}}^{(\mathrm{SH})}=0$ \\
\hline
\end{tabular}

Burada; $\phi_{\mathrm{u}}$, kesitteki göçme öncesi toplam eğriliği; $\phi_{\mathrm{y}}$, plastik mafsal kesitindeki etkin akma eğriliğini; $L_{\mathrm{s}}$, kesme açıklığını; $L_{\mathrm{p}}$, plastik mafsal boyunu; $d_{\mathrm{b}}$ ise düğüm noktasındaki donatıların ortalama çapını ifade etmektedir. $\phi_{\mathrm{u}}$, Denklem (1)'de verilen beton ve donatı çeliği birim şekil değiştirmeleri ve kesite etkiyen eksenel kuvvet dikkate alınarak yapılan analizden elde edilmektedir.

$$
\begin{gathered}
\left(\varepsilon_{\mathrm{s}}\right)^{(G \ddot{O})}=0.4 \varepsilon_{s u} \\
\left(\varepsilon_{\mathrm{c}}\right)^{(G \ddot{O})}=0.0035+0.04 \sqrt{\omega_{w e}} \leq 0.018
\end{gathered}
$$

Denklem (1.a)' da verilen $\varepsilon_{s u}$, maksimum dayanıma karş1 gelen donatı birim uzamasını ifade etmekte olup S220 donat1 sınıfı için 0.12, S420 donatı sınıfı için 0.08 alınmaktadır. Denklem (1.b)'de verilen $\omega_{w e}$ ise etkin sargı donatısının mekanik donatı oranını ifade etmekte olup dikdörtgen kesitler için Denklem (2) ile elde edilmektedir.

$$
\omega_{w e}=\alpha_{s e} * \rho_{s h, \min } * \frac{f_{y w e}}{f_{c e}}
$$

Denklem (2)'de verilen $\rho_{s h, m i n}$ dikdörtgen kesitte iki yatay doğrultuda hacimsel enine donatı oranının küçük olanını; $f_{y w e}$, enine donatının ortalama (beklenen) akma dayanımı; $f_{c e}$ beton ortalama (beklenen) basınç dayanımını; $\alpha_{s e}$ ise sarg1 donatıs1 etkinlik katsayısını ifade etmektedir. $\rho_{\text {sh,min }}$ Denklem (3) ile $\alpha_{s e}$ ise Denklem (4) ile elde edilmektedir.

$$
\begin{gathered}
\rho_{s h}=\frac{A_{s h}}{b_{k} s} \\
\alpha_{s e}=\left(1-\frac{\sum \alpha_{i}^{2}}{6 b_{o} h_{o}}\right)\left(1-\frac{s}{2 b_{o}}\right)\left(1-\frac{s}{2 h_{o}}\right)
\end{gathered}
$$

Burada; $A_{s h}$ ve $\rho_{s h}$ sırasıyla göz önüne alınan doğrultuda enine donatının alanını ve hacimsel oranını, $b_{k}$ dik doğrultudaki çekirdek boyutunu, $\mathrm{s}$ enine donatı aralığını, $b_{0}$ ve $h_{0}$ sarg1 donatısı eksenlerinden ölçülen sarg1lı beton boyutlarını, $a_{i}$ bir etriye kolu veya çiroz tarafindan mesnetlenen boyuna donatıların eksenleri arasındaki uzaklığı göstermektedir.

TBDY (2018) [1]'de verilen hasar sinırları ve hasar bölgeleri Şekil 2'de gösterilmiştir.

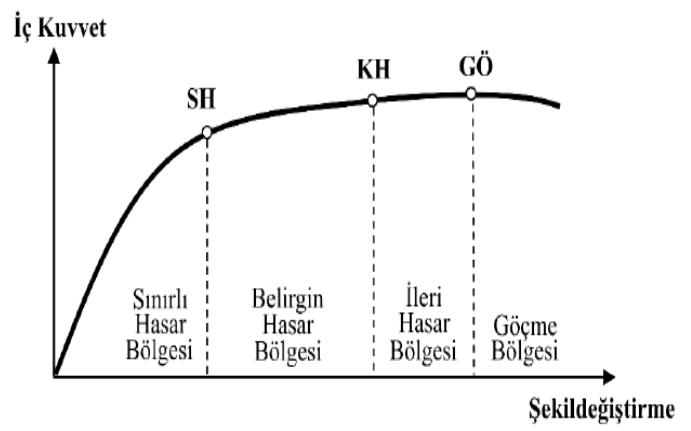

Şekil 2. TBDY (2018) [1]'de verilen kesit hasar sınırları ve hasar bölgeleri

\subsection{Performans seviyeleri}

\subsubsection{DBYBHY 2007'e göre performans seviyeleri}

DBYBHY [2]'de Hemen Kullanım (HK) performans düzeyi, Can Güvenliği (CG) performans düzeyi ve Göçme Öncesi (GÖ) performans düzeyi olmak üzere 3 performans düzeyi verilmiştir. GÖ performans düzeyini sağlayamayan binalar Göçme Durumu'ndadır. Çalışma kapsamında okul türü bir bina incelendiğinden, DBYBHY (2007) [2]'e göre binanın 50 yılda aşılma olasılığ $1 \% 10$ olan depremler için hedef performans seviyesi HK, 50 yılda aşılma olasıllı̆g $1 \% 2$ olan depremler için ise CG'dir. DBYBHY (2007) [2]'e göre betonarme binaların $\mathrm{HK}$ ve $\mathrm{CG}$ performans seviyelerini sağlamaları için gerekli koşullar Tablo 3'te verilmiştir. Gevrek olarak hasar gören elemanlar Tablo 3'e dâhil edilmemeli, bu elemanlar güçlendirilmelidir. 
Tablo 3. DBYBHY (2007) [2]'de verilen performans seviyesi koşulları

\begin{tabular}{|c|c|c|}
\hline $\begin{array}{c}\text { Performans } \\
\text { sevivesi }\end{array}$ & & Koşul \\
\hline HK & $*$ & $\begin{array}{l}\text { Yapılan analiz sonucu her bir katın her bir } \\
\text { doğrultusunda, Belirgin Hasar Bölgesi'ndeki } \\
\text { kirişlerin sayısı ilgili doğrultudaki toplam kiriş } \\
\text { sayısına oranı en fazla } 0.1 \text { olabilir. } \\
\text { İleri Hasar Bölgesi ve Göçme Bölgesine geçen } \\
\text { kiriş olmamalıdır. } \\
\text { Belirgin Hasar Bölgesi, İleri Hasar Bölgesi ve } \\
\text { Göçme Bölgesine geçen düşey taşıyıcı eleman } \\
\text { olmamalıdır. }\end{array}$ \\
\hline $\mathrm{CG}$ & $>$ & $\begin{array}{l}\text { Yapılan analiz sonucu her bir katın her bir } \\
\text { doğrultusunda, İleri Hasar Bölgesi'ndeki kirişlerin } \\
\text { sayısı İlgili doğrultudaki toplam kiriş sayısına } \\
\text { oranı en fazla } 0.3 \text { olabilir. } \\
\text { İleri Hasar Bölgesi'ndeki kolonların, her bir katta } \\
\text { kolonlar tarafından taşınan kesme kuvvetine oranı } \\
\text { normal katlarda } 0.2 \text { 'den daha az olmalıdır. Bu oran } \\
\text { en üst katta en fazla } 0.4 \text { olabilir. } \\
\text { Göçme bölgesine geçen düşey taşıyıcı eleman } \\
\text { olmamalıdır. } \\
\text { Herhangi bir katta, iki ucu birden Minimum Hasar } \\
\text { Sınırını aşan düşey elemanların taşıdığı kesme } \\
\text { kuvvetlerinin, o kattaki tüm düşey elemanlar } \\
\text { tarafindan taşınan kesme kuvvetine oranı en fazla } \\
0.3 \text { olmalıdır. }\end{array}$ \\
\hline
\end{tabular}

\subsubsection{TBDY 2018'e göre performans seviyeleri}

TBDY (2018) [1]'de Kesintisiz Kullanım(KK) performans düzeyi, Sınırlı Hasar ( $\mathrm{SH}$ ) performans düzeyi, Kontrollü Hasar (KH) performans düzeyi ve Göçmenin Önlenmesi (GÖ) performans düzeyi olmak üzere 4 performans düzeyi verilmiştir. Göçmenin Önlenmesi performans düzeyini sağlayamayan binalar Göçme Durumundadir.

Tablo 4. TBDY (2018) [1]'de verilen performans seviyesi koşulları

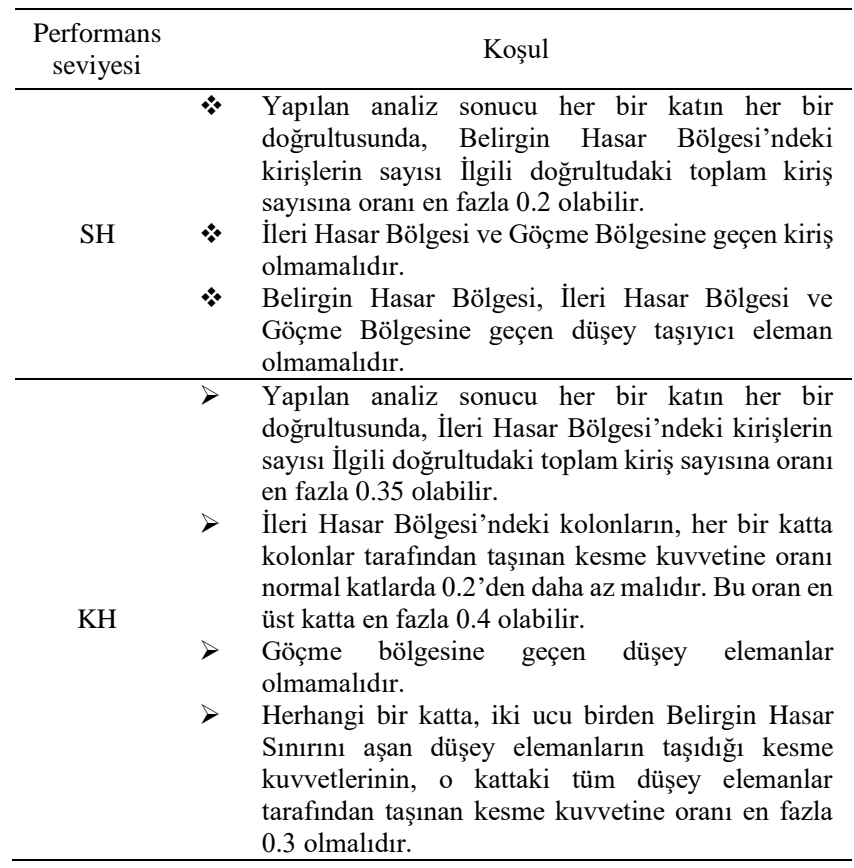

TBDY (2018) [1]'e göre incelenen binanın 50 yılda aşılma olasılığ $\%$ 50 olan depremler (DD-3 deprem düzeyi) için hedef performans seviyesi SH, 50 yılda aşılma olasılığ $\% 2$ olan depremler (DD-1 deprem düzeyi) için hedef performans seviyesi (KH)'dır. TBDY (2018) [1]'e göre betonarme binaların $\mathrm{SH}$ ve $\mathrm{KH}$ performans seviyelerini sağlamaları için gerekli koşullar Tablo 4'te verilmiştir. Gevrek olarak hasar gören elemanlar Tablo 4'e dâhil edilmemeli, bu elemanlar güçlendirilmelidir.

\section{Mevcut okul türü bir binanın deprem performansının değerlendirilmesi}

Çalışma kapsamında, 1986 yılında inşa edilen 4 katlı bir okul binası incelenecektir. Binanın her bir katında 22 adet kolon ve 2 adet perde duvar bulunmaktadır. Binanın tüm katlarının, kolon aplikasyon planı Şekil 3'te verilmiştir. Bina genel bilgileri aşağıda verilmiştir.

- Beton sinifi: C14

- Donati sinifi: S220

- Kat yüksekliği: $3.3 \mathrm{~m}$

- Yerel zemin sınıfi: DBYBHY 2007 [2]'e göre: Z3, TBDY 2018 [1]'e göre: ZD

- Bina deprem parametreleri:

$>$ DBYBHY 2007'ye göre: etkin yer ivmesi $\mathrm{A}_{0}: 0.3 \mathrm{~g}$ $>$ TBDY 2018'e göre,

DD-1 için $\mathrm{S}_{\mathrm{DS}}: 1.138 ; \mathrm{S}_{\mathrm{D} 1}: 0.567$

DD-2 için $\mathrm{S}_{\mathrm{DS}}: 0.726 \mathrm{~S}_{\mathrm{D} 1}: 0.327$

DD-3 için $\mathrm{S}_{\mathrm{DS}}$ : 0.338; $\mathrm{S}_{\mathrm{D} 1}: 0134$

- $\quad$ Bina düşey yükleri

$>$ Döşeme sabit yükü $=5.25 \mathrm{kN} / \mathrm{m}^{2}$

$>$ Döşeme hareketli yükü

Normal döșemelerde: $3.5 \mathrm{kN} / \mathrm{m}^{2}$

Koridorlarda: $5 \mathrm{kN} / \mathrm{m}^{2}$

$>$ İç ve dış duvar yükleri (sıva dahil): $5 \mathrm{kN} / \mathrm{m}$

Bina taşıyıcı sistemi SAP 2000 [15] programı kullanılarak modellenmiştir. Bina taşıyıcı sisteminin 3 boyutlu modeli Şekil 4 'te verilmiştir. 2 farklı yönetmelik için performans değerlendirilmesi yapılacağından 2 farklı Sap 2000 dosyası oluşturulmuştur. DBYBHY 2007 [2] esaslarına göre oluşturulan Sap 2000 modeli, Okul model_2007, TBDY 2018 [1]' esaslarına göre oluşturulan Sap 2000 modeli ise Okul model_2018 olarak isimlendirilmiştir.

Okul model_2018 Sap 2000 [15] modelinde kiriş, kolon ve betonarme perdelerin etkin kesit rijitlik çarpanları sırasıyla $0.35,0.7$ ve 0.5 alınmıştır. Okul model_2007 Sap 2000 [15] modelinde ise kirişlerin etkin kesit rijitlik çarpanları 0.4 alınmıştır. Düşey taşıyıcıların etkin kesit rijitlik çarpanlarının belirlenmesi için ise bina öncelikle düşey yükler altında analiz yapılmış ve düşey taşıyıcı elemanlara etkiyen eksenel yükler belirlenmiştir. Düşey taşıyıcıların etkin kesit rijitlik çarpanları elde edilen bu eksenel yüklere göre belirlenmiştir. Düşey taşıyıcı elemanların etkin kesit rijitlik çarpanları 0.4 ile 0.62 aralığında çıkmıştır. 


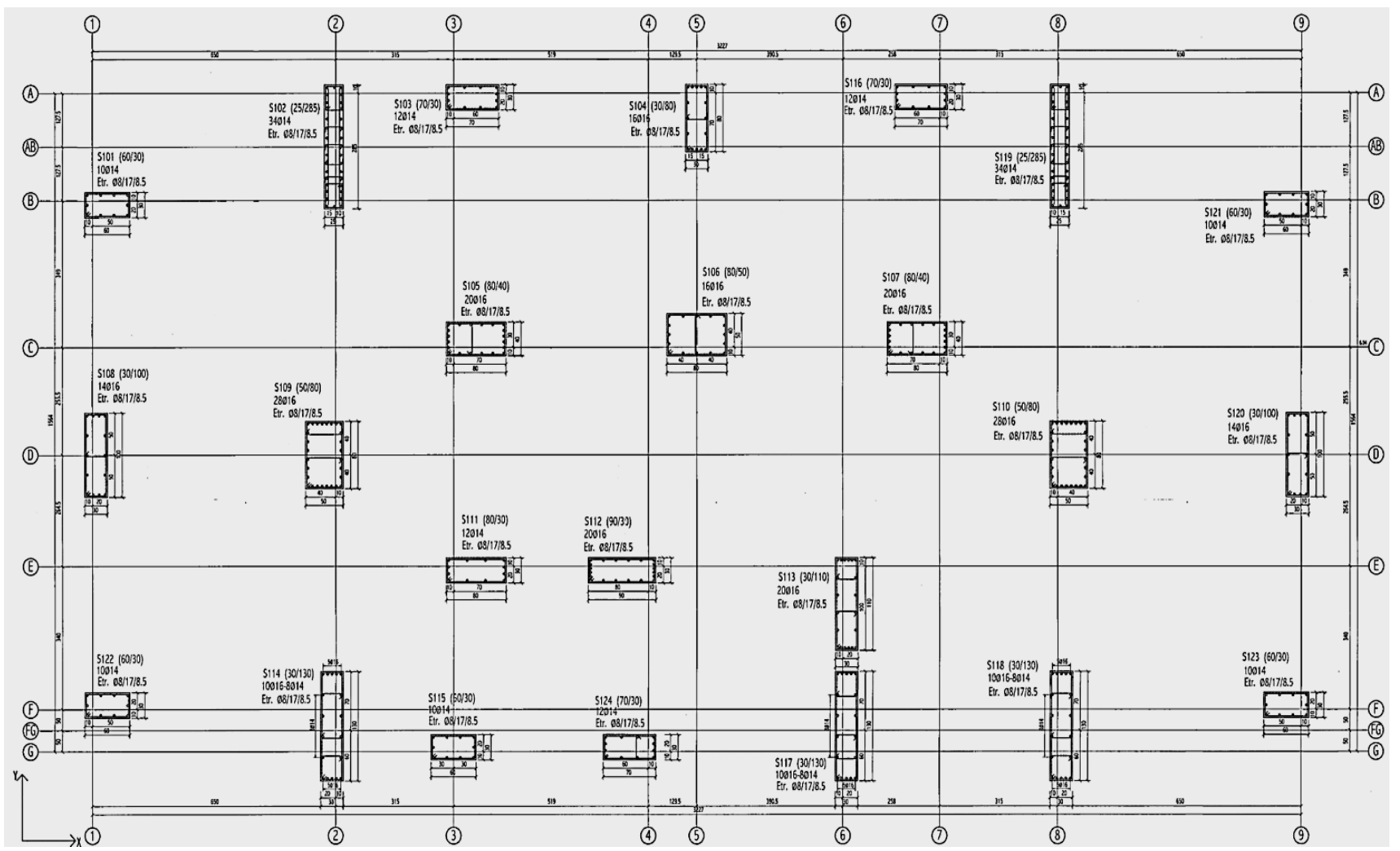

Şekil 3. Mevcut okul binasının kolon aplikasyon planı

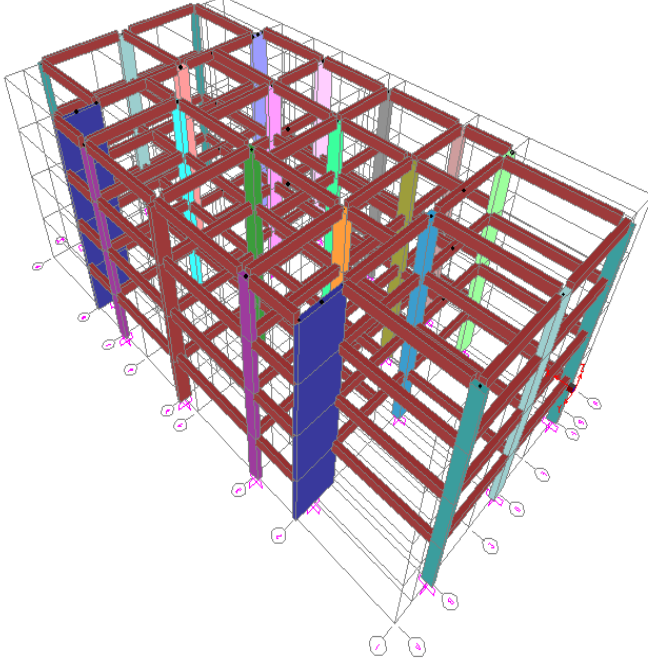

Şekil 4. Binanın 3 boyutlu taşıyıcı sistem modeli

Statik itme analizlerinde yapılan kabuller aşağıda maddeler halinde verilmiştir.

- Doğrusal olmayan davranış modeli olarak 'Yığılı Plastik Davranış Modeli' kullanılmıştır.

- Plastik şekildeğiştirmelerin düzgün yayılı olarak gerçekleştiği kabul edilmiştir.

- Plastik mafsal boyu (Lp), kesitin çalışan doğrultudaki boyutunun yarısı olarak alınmıştır.
- Plastik mafsallar kolon ve kirişlerde net açıklıklarının iki ucuna, perdelerde ise alt uçlara koyulmuştur.

- Kolon ve perdelerde plastikleşmenin eksenel kuvvet ve iki eksenli eğilme momenti (P-M2M3)etkisinde gerçekleştiği, kirişlerde tek eksenli (M3) gerçekleştiği kabul edilmiştir.

- Kesme açıklığı (Ls), kolon ve kirişlerde açıklığın yarısı, perdelerde ise her katın tabanından son katta bulunan perdenin tepesine olan uzaklığın yarısı olarak hesaplanmıştır.

Binanın taşıyıcı eleman kesitlerinde oluşacak hasarların belirlenebilmesi için elemanların uçlarına atanacak plastik mafsalın özelliklerinin tanımlanması gerekmektedir. Taşıyıcı elemanların plastik mafsal özeliklerinin tanımlanabilmesi için ise kesitlerin karşılıklı etkileşim diyagramlarının (akma yüzeyleri) ve moment eğrilik bağıntılarının elde edilmesi gerekmektedir.

$\mathrm{Bu}$ çalışmada kesitlerin akma yüzeyleri ve momenteğrilik bağıntıları SAP 2000 [15] programının Section Designer bölümü kullanılarak elde edilmiştir. 2007 ve 2018 deprem yönetmeliklerine göre kesit hasar sınırların belirlenmesi için ise moment eğrilik analizlerinden elde edilen veriler Excel formatında oluşturulan bir dosya aktarılmıştır. Her bir kesitin plastik mafsal özellikleri, söz konusu Excel yardimiyla SAP 2000 [15] programina aktarılmak üzere oluşturulmuştur. Oluşturulan Excel' in 2018 deprem yönetmeliği için hazırlanan görüntüsü Şekil 5'te verilmiştir. 

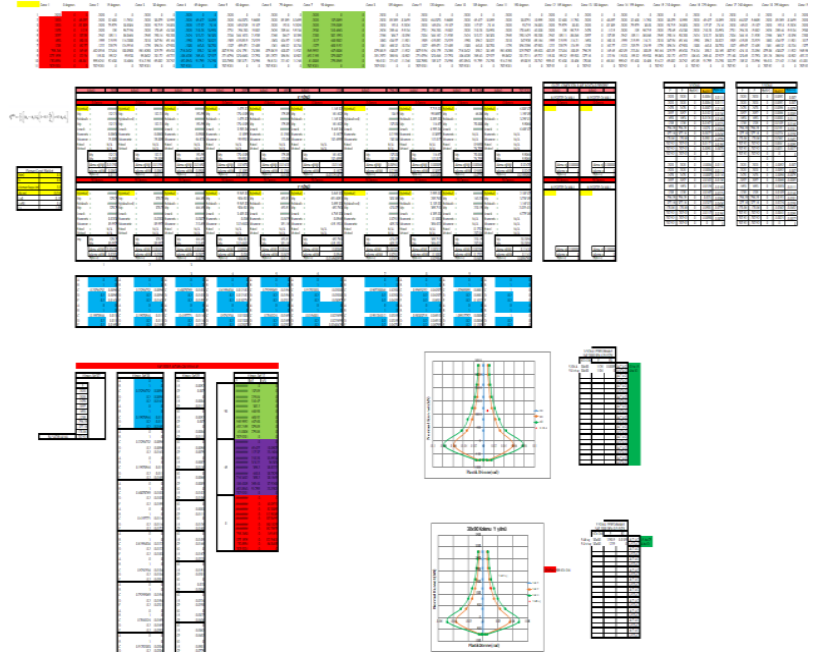

Şekil 5. Kesitlerin plastik mafsal özelliklerinin belirlenmesi için oluşturulan Excel'in görüntüsü

Her bir kesite plastik mafsallar atandıktan sonra tek modlu itme analizinin tanımlanabilmesi için deprem doğrultusunda hakim titreşim mod şekli ile orantılı olacak şekilde yük dağılımının belirlenmesi gerekmektedir. Katlara uygulanacak yük dağılımı, ilgili doğrultunun mod şekli genliği ile katlara ait kütlelerin çarpımıyla elde edilen değerlere göre yapılır. Katlara uygulanacak yük dağılımının belirlenmesi için Okul Model_2007 ve Okul Model_2018 SAP 2000 dosyaları modal analize tabi tutulmuştur. Modal analiz sonucu elde edilen mod şekli genlikleri kat kütleri ile çarpılarak ilgili doğrultu için katlara uygulanacak yük dağılımları belirlenmiştir (Şekil 6). Elde edilen yükler kat kütle merkezine uygulanmıştır.
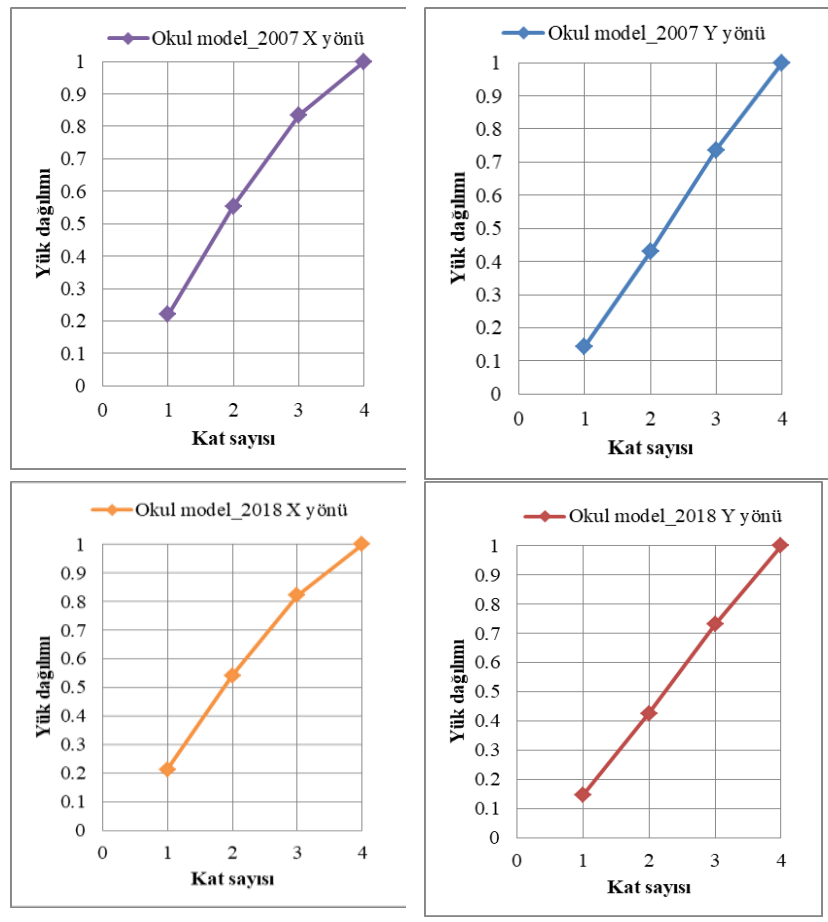

Şekil 6. Kat hizalarına etkiyen yatay yük dağılımları
TBDY 2018 [1]'e göre itme analizinden önce, statik düşey yüklerin taşıyıcı sisteme doğrusal olmayan statik hesap ile uygulanması gerekmektedir. Statik düşey yükler Denklem (5) ile hesaplanmaktadır. Doğrusal olmayan statik hesap ile bulunan iç kuvvet ve şekildeğiştirmeler yatay deprem hesabının başlangıç değerleri olarak göz önüne alınmalıdır.

$$
G+n Q+0.3 E_{d}^{(Z)}
$$

Burada G sabit yük etkisini, Q hareketli yük etkisini, n hareketli yük azaltma katsayısını, $E_{d}^{(Z)}$ ise Denklem (6) ile elde edilen düşey deprem etkisini ifade etmektedir.

$$
E_{d}^{(Z)}=2 / 3 * S_{D S} * G
$$

TBDY 2018'e göre mevcut okul türü binaların, DD-1 deprem düzeyi için Kontrolü Hasar (KH) ve DD-3 deprem düzeyi için Sınırlı Hasar ( $\mathrm{SH}$ ) hedef performans seviyelerini sağlamaları gerekmektedir. Bu yüzden 2 farklı deprem düzeyine göre itme analizi gerçekleştirmek gereklidir. Denklem (6)'da yer alan $\mathrm{S}_{\mathrm{DS}}$ katsayısı da deprem düzeyine bağlı olarak değiştiğinden Okul Model_2018 SAP 2000 dosyas1 Okul Model_2018_DD1 ve Okul Model_2018_DD3 olmak üzere iki farklı dosya halinde kaydedilmiştir. Okul Model_2018_DD1; DD1 deprem düzeyine göre oluşturulan SAP 2000 dosyasın1, Okul Model_2018_DD3; DD-3 deprem düzeyine göre oluşturulan SAP 2000 dosyasını ifade etmektedir.

DD1 için $\mathrm{S}_{\mathrm{DS}}$ değeri 1.138, DD3 için ise 0.338 olarak, Denklem (5)'de yerine koyulmuş ve itme analizlerinin başlangıç adımı her iki deprem düzeyi için elde edilmiştir. Elde edilen statik düşey yükleme Okul Model_2018_DDI Sap 2000 dosyası için Denklem (7.a)'da, Okul Model_2018_DD3 Sap 2000 dosyası için ise Denklem (7.b)'de verilmiştir. İncelenen bina okul türü olduğundan Denklem (5) yer alan katsayısı 0.6 alınmıştır.

$$
\begin{aligned}
& 1.2276 G+0.6 Q \\
& 1.0676 G+0.6 Q
\end{aligned}
$$

DBYBHY 2007 [2]'e göre yapılacak olan doğrusal olmayan statik analizde Denklem (5)'de yer alan düşey deprem etkisi dikkate alınmamaktadır. DBYBHY 2007'e göre yapılacak olan itme analizlerinin başlangıç adımı olan doğrusal olmayan statik analiz bağıntısı Denklem (8)'de verilmiştir.

$$
G+0.6 Q
$$

Denklem (7) ve Denklem (8) ile bulunan G ve Q yüklerinin önündeki katsayılar, ilgili SAP 2000 dosyasının statik düşey yüklemesine 'Scale Factor' olarak yansıtılmıştır

DBYBHY 2007 [2]'e göre mevcut okul türü binaların, 50 yılda aşılma olasılığı \%2 olan depremler için Hemen Kullanım (HK) ve 50 yılda aşılma olasılığı \%10 olan depremler için Can Güvenliği (CG) hedef performans seviyelerini sağlamaları gerekmektedir. Bu yüzden 2 aşılma 
olasıllğıı göre itme analizi gerçekleştirmek gereklidir. Bunun için Okul Model_2007 SAP 2000 dosyas1 50 y1lda aşılma olasılığ $1 \% 2$ olan depremler için Okul Model_2007_\%2 olarak, 50 yılda aşılma olasıllı̆ı $\% 10$ olan depremler için ise Okul Model_2007_\%10 olmak üzere iki farklı dosya halinde kaydedilmiştir.

Tüm modellerin statik itme analizi verileri tanımlandıktan sonra bu modellerin her birinin iki doğrultuda ayrı ayrı itme analizi yapılmıştır. Analizlerin sonucunda $\mathrm{X}$ ve $\mathrm{Y}$ doğrultusuna ait 6 adet kapasite eğrisi elde edilmiştir. X yönü için yapılan statik itme analizi sonucu elde edilen kapasite eğrileri Şekil 7.a'da, X yönü için yapılan statik itme analizi sonucu elde edilen kapasite eğrileri Şekil 7.b'de verilmiştir

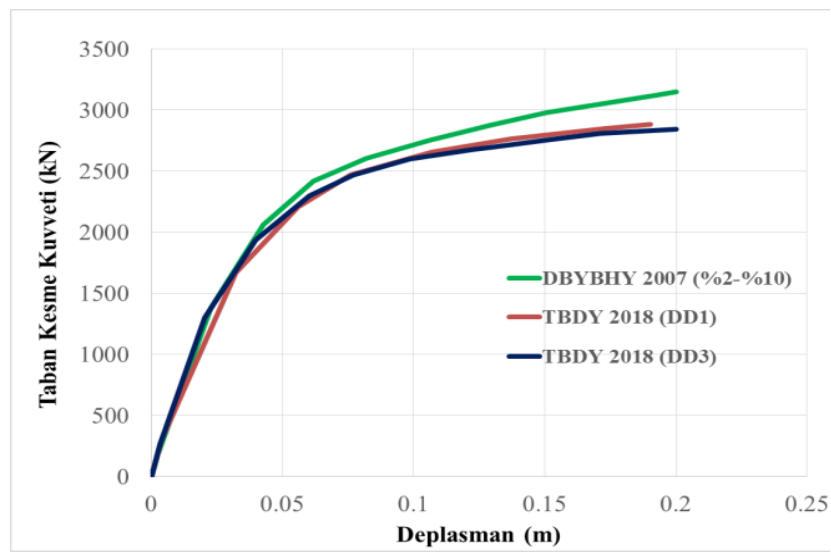

Şekil 7.a Tüm modellerin $X$ yönü kapasite eğrileri

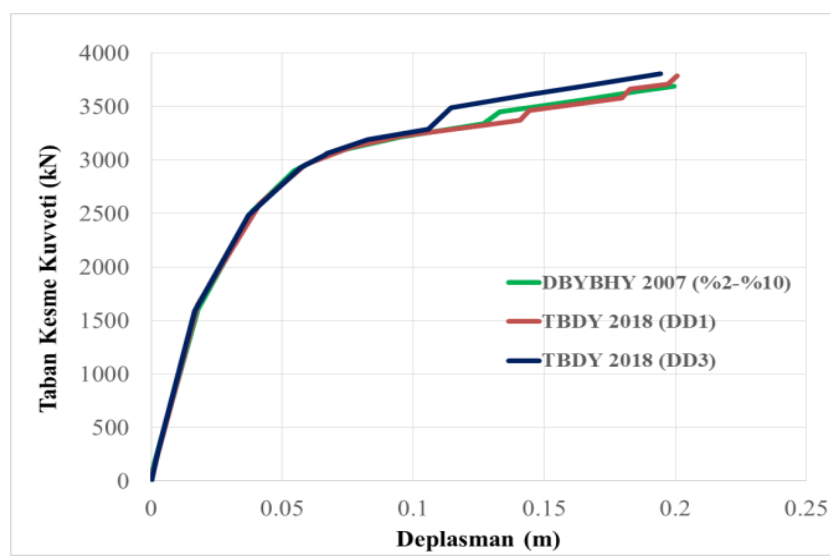

Şekil 7.b Tüm modellerin Y yönü kapasite eğrileri

Statik itme yöntemiyle deprem performansı belirlenecek olan binaların hedef yerdeğiştirme istemi $\mathrm{X}$ ve $\mathrm{Y}$ yönü için ayr1 ayr1 belirlenmelidir. Her bir modelin Hedef yerdeğiştirme istemlerinin belirlenmesi için Excel formatında bir dosya oluşturulmuştur. İncelenen binanın tüm modellerinin hedef yerdeğiştirme istemlerinin belirlenmesinde kullanılan grafikler Şekil 8'de verilmiştir.

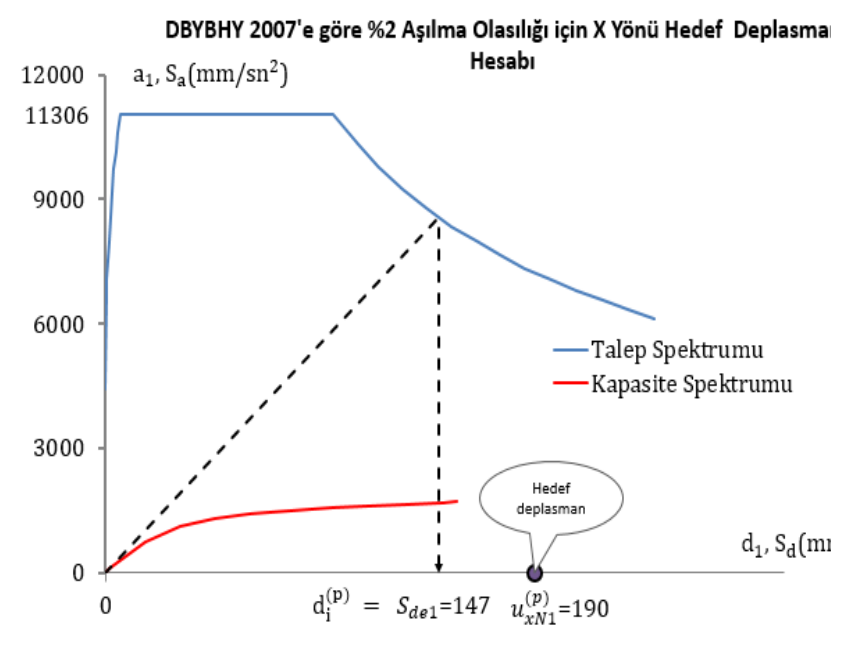

Şekil 8.a. DBYBHY 2007 [2]'e göre \%2 aşılma olasılı̆̆g için $\mathrm{X}$ yönü hedef deplasman hesabı

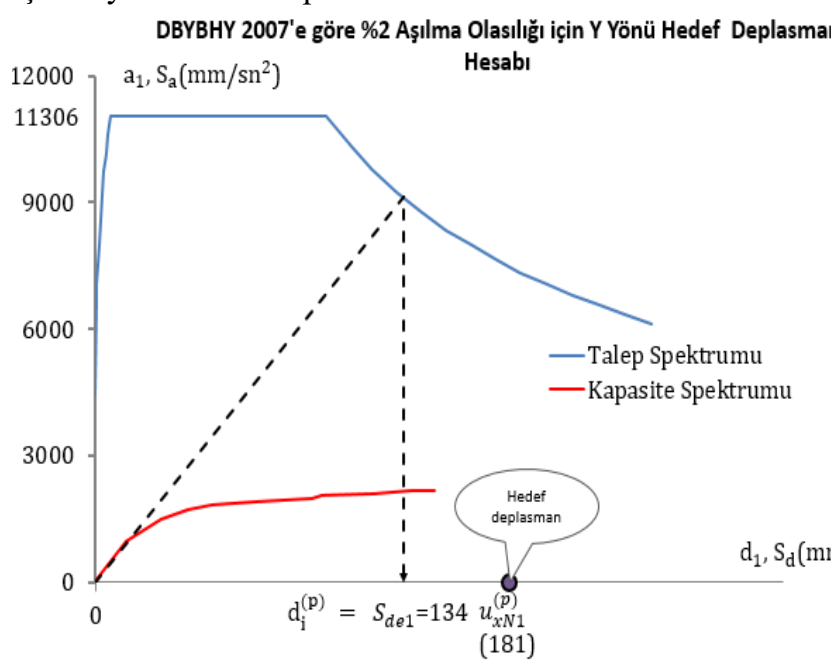

Şekil 8.b. DBYBHY 2007 [2]'e göre \%2 aşılma olasıllğ̆1 için Y yönü hedef deplasman hesabı

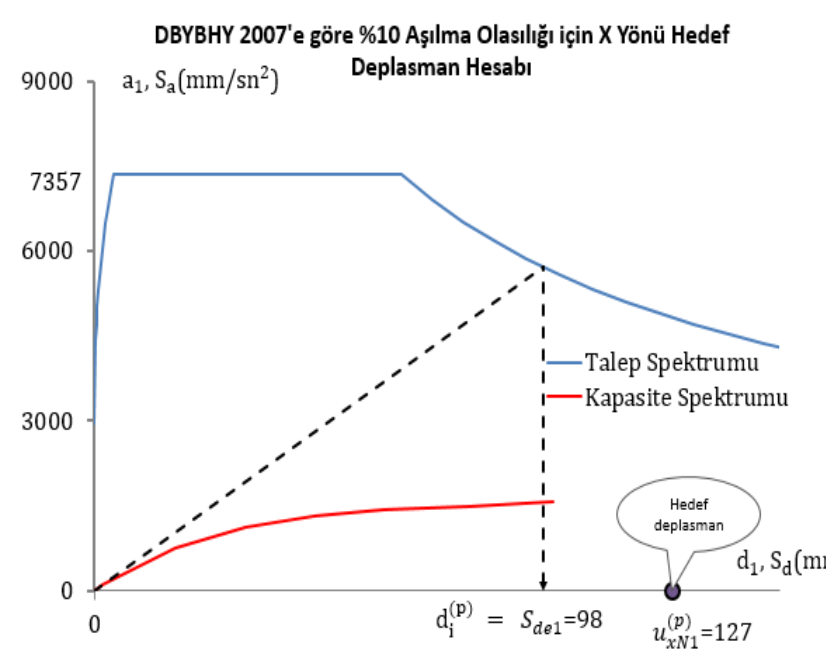

Şekil 8.c. DBYBHY 2007 [2]'e göre \%10 aşılma olasıllı̆̆ için $\mathrm{X}$ yönü hedef deplasman hesabı 


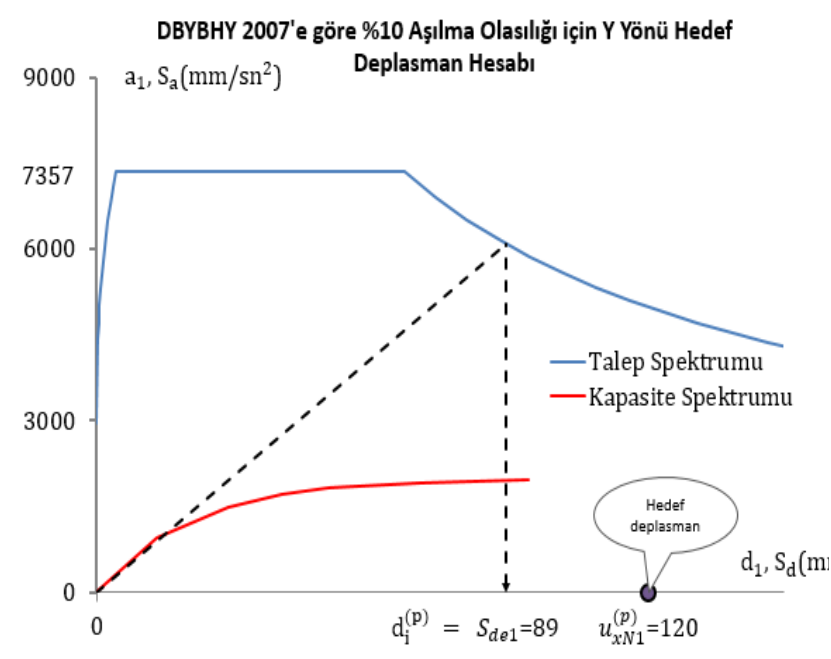

Şekil 8.d. DBYBHY 2007 [2]'e göre \%10 aşılma olasılığ1 için Y yönü hedef deplasman hesabı

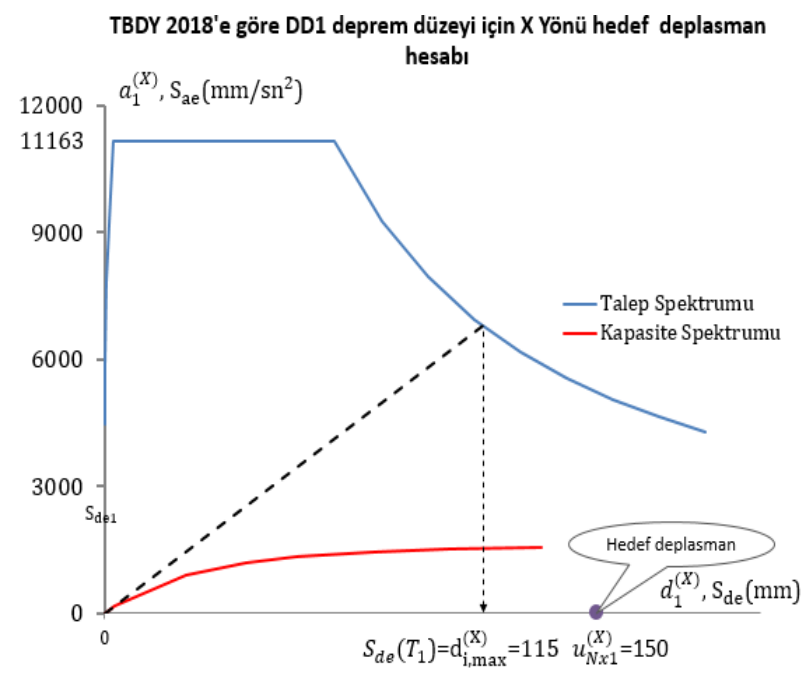

Şekil 8.e. TBDY 2018 [1]'e göre DD1 deprem düzeyine için X Yönü hedef deplasman hesabı

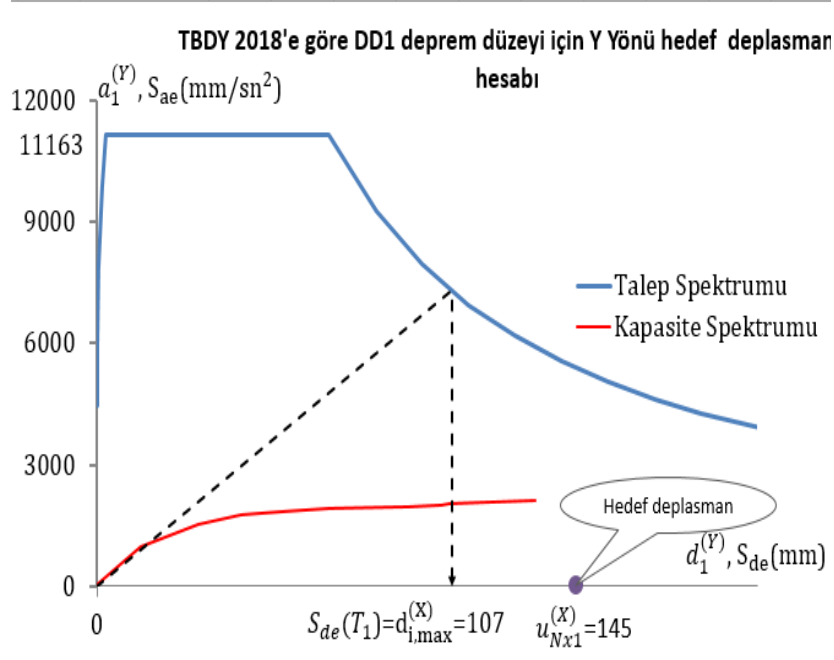

Şekil 8.f. TBDY 2018 [1]'e göre DD-1 deprem düzeyine için Y Yönü hedef deplasman hesabı

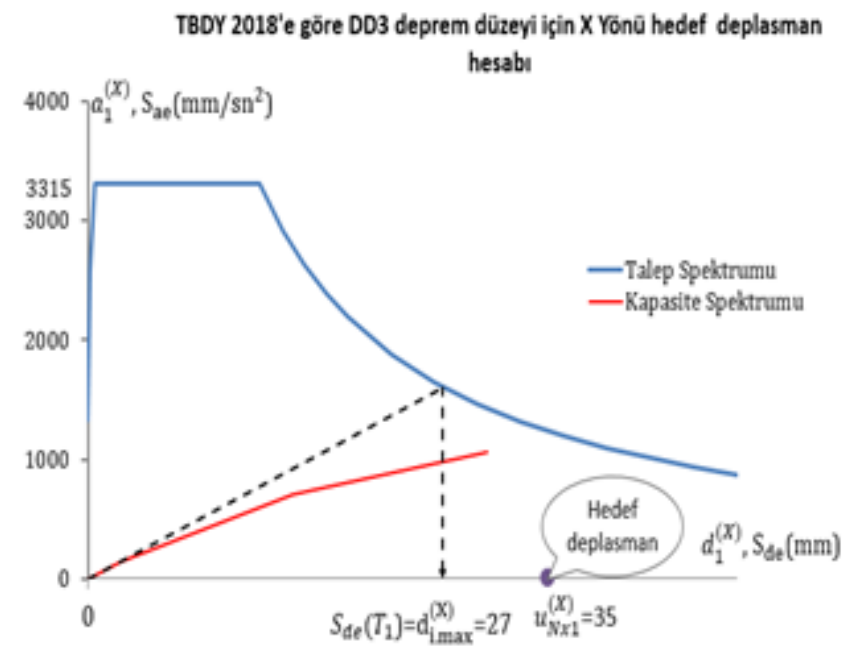

Şekil 8.h. TBDY 2018 [1]'e göre DD-3 deprem düzeyine için X Yönü Hedef Deplasman Hesabı

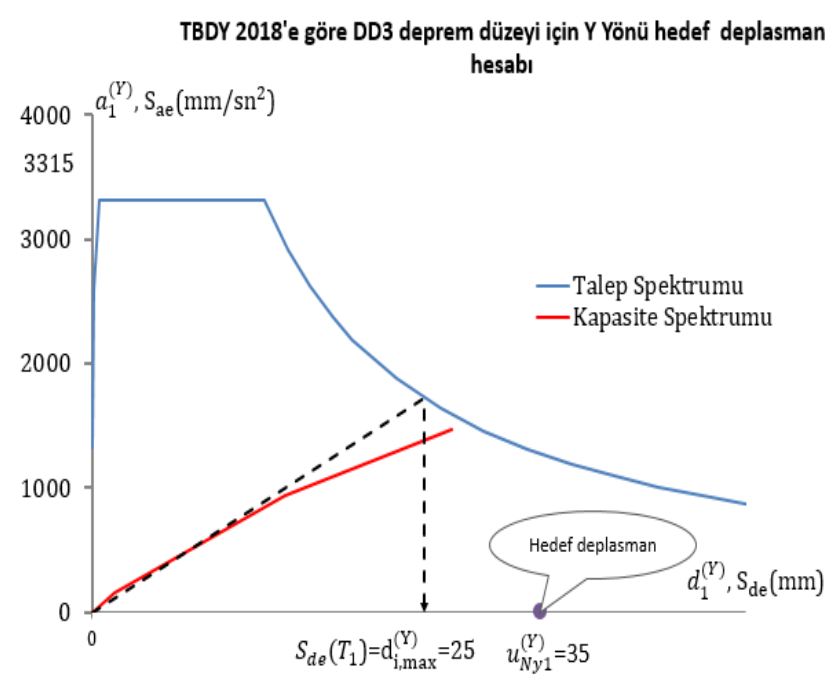

Şekil 8.i. TBDY 2018 [1]'e göre DD-3 deprem düzeyine için Y Yönü Hedef Deplasman Hesabı

İncelenen bina, her iki deprem yönetmeliğinin iki deprem düzeyi ve iki doğrultusunun her biri için ayrı ayrı olarak yer değiştirme istemine kadar statik itme analizine tabi tutulmuştur. Deprem yönetmeliği, deprem düzeyi ve deprem doğrultusu dikkate alındığında toplamda 8 farklı statik itme analizi sonucu elde edilmiştir. Yapılan statik itme analizleri ile her bir taşıyıcı elemanda meydana gelen hasarlar belirlenmiştir.

DBYBHY 2007 [2] 'e göre yapılan çözümlerde her bir elemanın Sap 2000 [15] programından elde edilen hasarları, bina performans seviyesini belirlemek için doğrudan kullanılmıştır. TBDY 2018 [1]'e göre yapılan çözümlerde ise her bir elemanın Sap 2000 [15] programından elde edilen hasarları bina performans seviyesini belirlemek için doğrudan kullanılamamıştır. Çünkü TBDY 2018 [1] madde 15.7.1.2'ye göre eğer betonarme elemanların boyuna donatıları nervürsüz (düz) donatı çeliği ile düzenlenmişse, donatı çeliği birim şekildeğiştirme talebi ve plastik dönme talebi 1.5 ile çarpılarak arttırılması gerekmektedir. İncelenen binada boyuna donatılar nervürsüz donatı çeliği olduğundan 
Sap 2000 [15] programında yapılan analiz sonucu elde edilen plastik dönmeler $\% 50$ artırılmış, elde edilen artırılmış plastik dönmeler plastik dönme üst sınırları ile kıyaslanarak her bir elemanın hasarı yeniden belirlenmiştir.

Düşey elemanların hasarı kesite etkiyen normal kuvvet değerine bağlı olarak değiştiğinden öncelikle her bir kesitin Normal kuvvet-Plastik dönme kapasitesi grafikleri oluşturulmuştur. Her bir düşey eleman kesitinin Normal kuvvet-Plastik dönme kapasitesi grafikleri için Section Designer'de yapılan moment eğrilik analizlerinden faydalanmıştır. Örnek olması için S104 kolonunun excel dosyasında hazırlanan Normal kuvvet-Plastik dönme grafiği Şekil 9'da verilmiştir. Grafikte; en içteki Y ekseni boyunca devam eden mavi eğri SH sınırını, ortadaki turuncu eğri $\mathrm{KH}$ sınırını ve en dıştaki yeşil eğri GÖ hasar sınırını, göstermektedir.

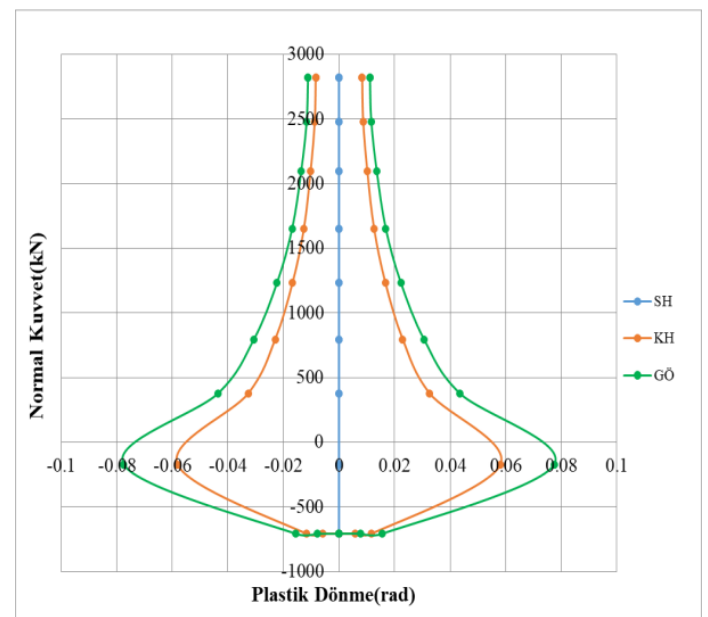

Şekil 9. S104 kolon kesitinin normal kuvvet-plastik dönme grafiği

Yapılan analiz sonucu düşey elemanlarda meydana gelen plastik dönmeler 1.5 ile çarpılmış, her bir kesit için elde edilen bu artırılmış plastik dönme ile normal kuvvet çifti ilgili kesitin normal kuvvet - plastik dönme grafiği üzerinde gösterilmiştir. Eğri üzerindeki hasar sınır eğrilikleri dikkate alınarak ilgili kesitin hasarı belirlenmiştir. $\mathrm{Bu}$ işlem kolonların alt ve üst uç kesitleri için perde duvarların ise alt uç kesitleri için yapılmıştır. S104 kolonunun alt ucunun, DD1 deprem düzeyine bağlı olarak X hesap doğrultusu için belirlenen hasarı Şekil 10'da verilmiştir.

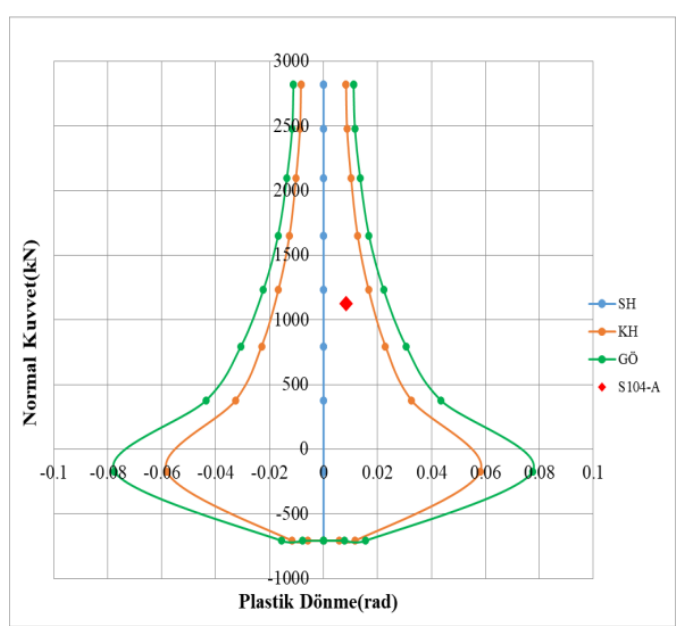

Şekil 10. S104 kolon kesitinin hasar durumunun belirlenmesi

Şekil 10 incelendiğinde S104 kolonunun alt ucu SH ile $\mathrm{KH}$ arasında kalmaktadır. Bu durumda bu kolonun alt ucu belirgin hasar bölgesinde kalmaktadır. Kolonun üst ucunda plastik dönme meydana gelmediğinden grafik üzerinde gösterilmemiştir.

Kiriş kesitlerine normal kuvvet etki etmediği kabul edildiğinden bu kesitler için normal kuvvet-plastik dönme grafiklerini kullanmaya gerek kalmamıştır. Analiz sonucu elde edilen plastik dönmeler \%50 artırılmış, elde edilen artırılmış plastik dönmeler ile plastik dönme hasar sınır değerleri kıyaslanarak kiriş kesitlerinin hasarları tespit edilmiştir.

Kiriş kesitlerinin deprem yönetmeliği, deprem düzeyi ve deprem doğrultusuna bağlı olarak belirlenen hasar bölgeleri Şekil 11'de verilmiştir

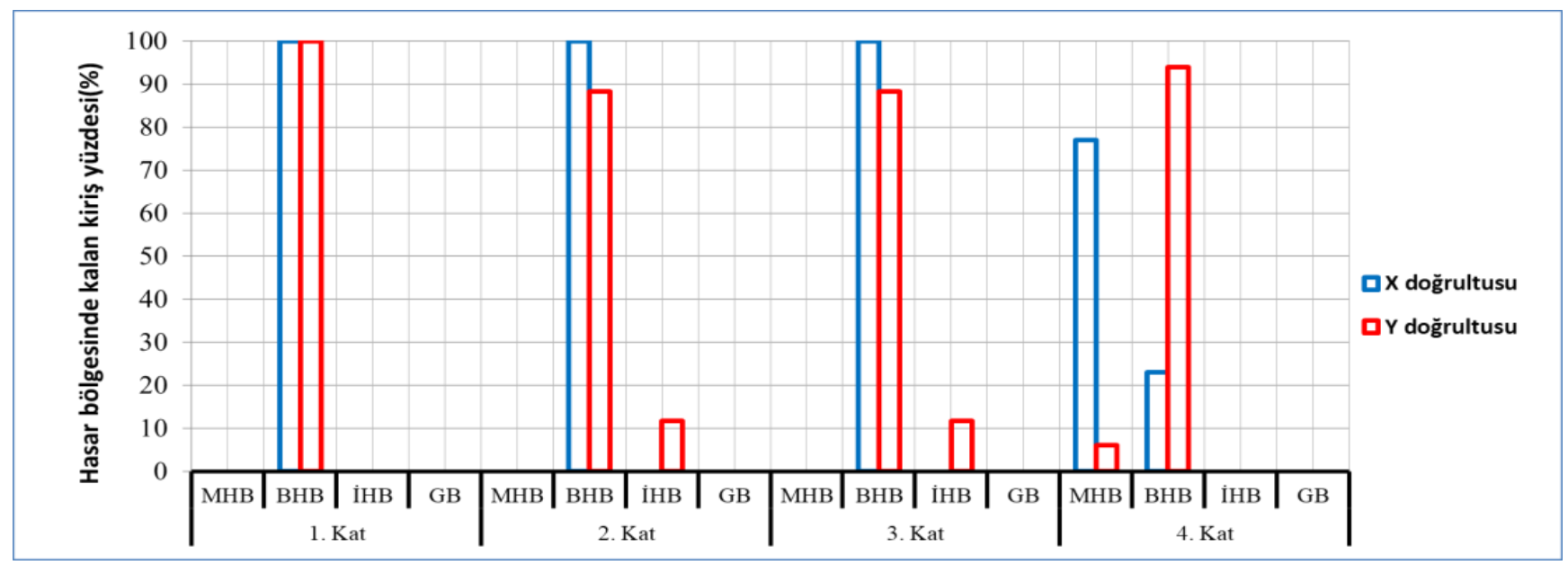

Şekil 11.a. DBYBHY 2007 [2]'e göre \%2 aşılma olasılı̆̆g için elde edilen kiriş hasar bölgeleri 


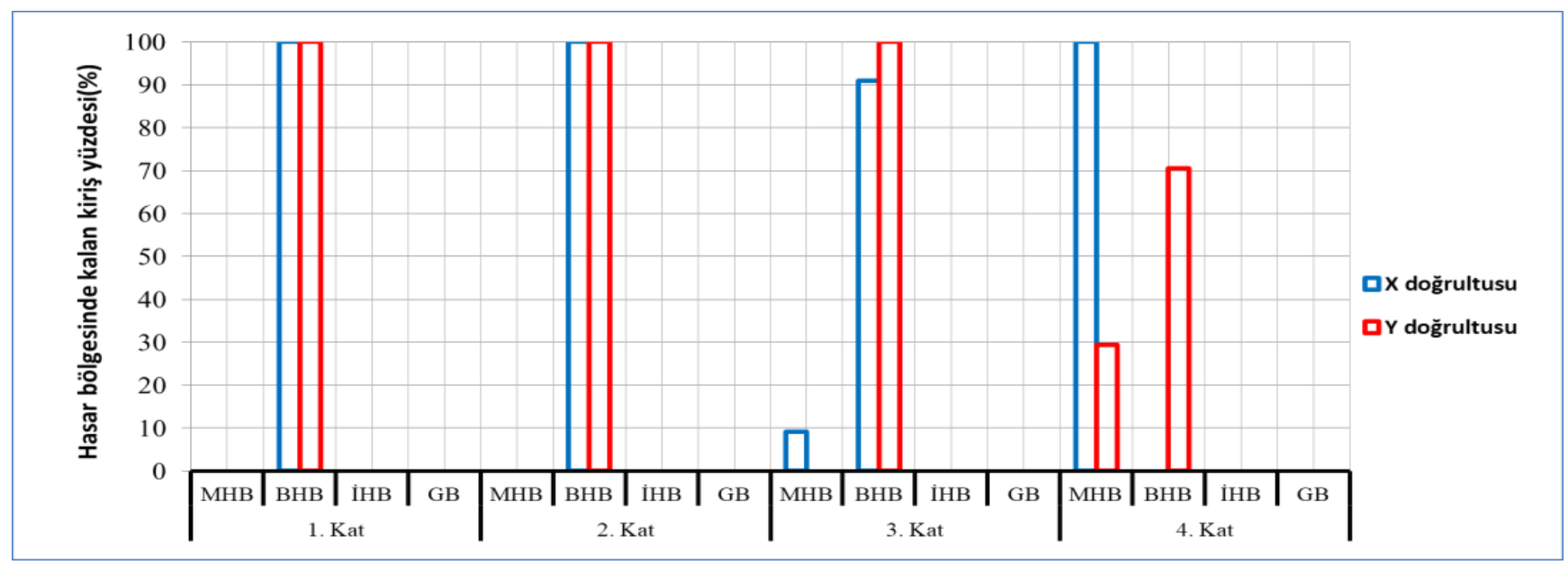

Şekil 11.b. DBYBHY 2007 [2]'e göre \%2 aşılma olasıllı̆ı için elde edilen kiriş hasar bölgeleri

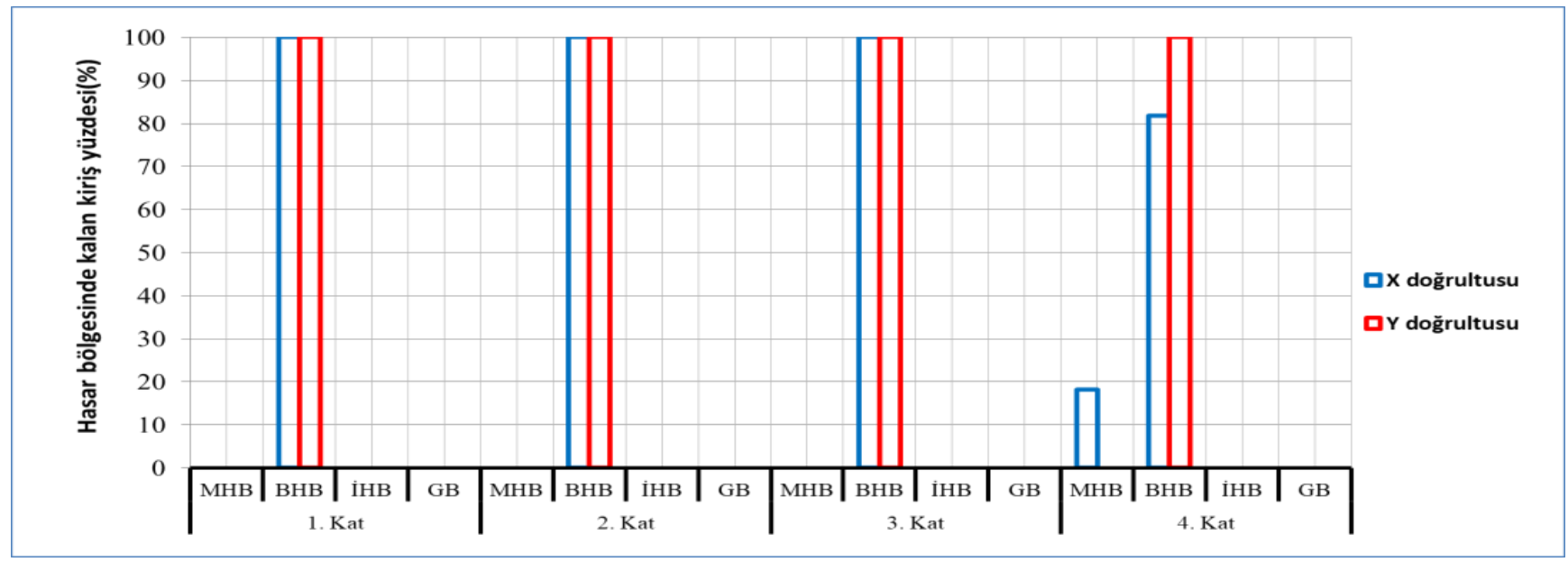

Şekil 11.c. TBDY 2018 [1]'e göre DD-1 için elde edilen kiriş hasar bölgeleri

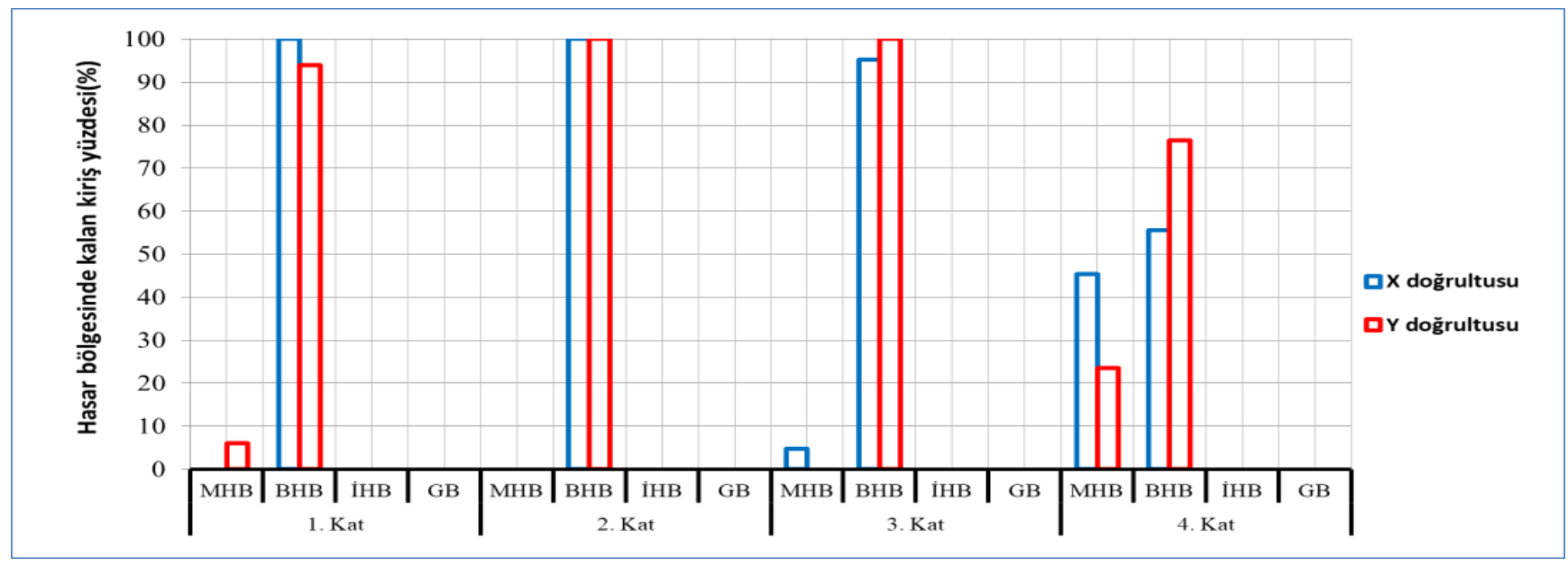

Şekil 11.d. TBDY 2018 [1]'e göre DD-3 için elde edilen kiriş hasar bölgeleri

Kolon ve perde duvar kesitlerinin deprem yönetmeliği, deprem düzeyi ve deprem doğrultusuna bağlı olarak belirlenen hasar bölgeleri Şekil 12'de verilmiştir. Bina performans seviyesinin belirlenmesi için İleri Hasar Bölgesi (İHB)'nde kalan düşey taşıyıcı elemanların taşıdığı kesme kuvvetinin kat kesme kuvvetine oranının belirlenmesi gerekmektedir. Şekil 12'de sütunların üzerinde yazan yüzdelik ifadeler, İleri hasar bölgesinde kalan düşey taşıyıcı elemanların taşıdığı kesme kuvvetinin kat kesme kuvvetine oranını göstermektedir. Örneğin Şekil 12.a'ya bakıldığında, 1. Katta, X hesap doğrultusunda, Minimum Hasar Bölgesi (MHB) ve Göçme Bölgesi (GB)'nde kalan düşey taşıyıcı eleman olmadığı ve İleri Hasar Bölgesinde kalan düşey elemanların, 1. kattaki düşey elemanlar tarafından taşınan kesme kuvvetine toplam katkısının \% 31 olduğunu göstermektedir. 


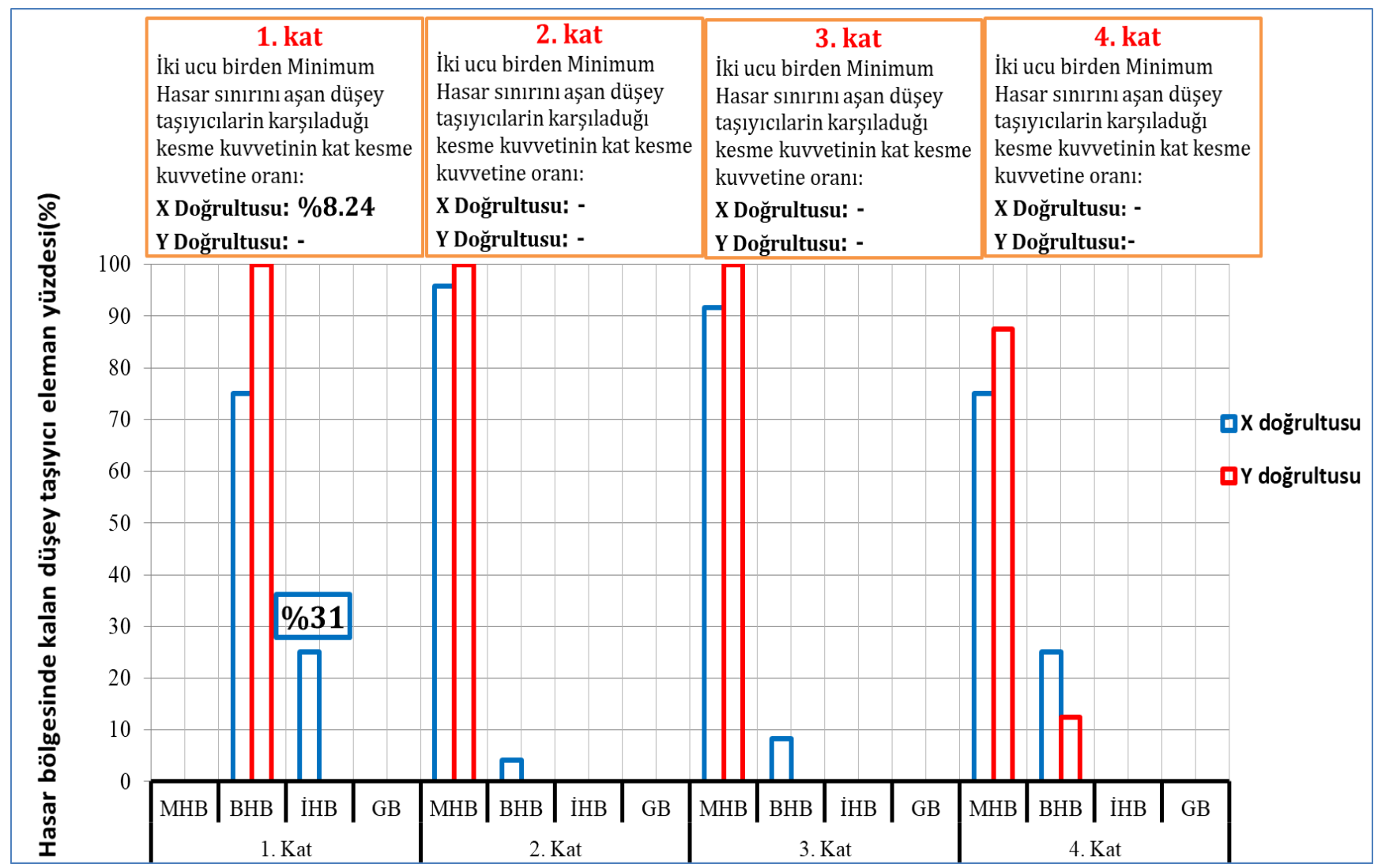

Şekil 12.a. DBYBHY 2007 [2]'e göre \%2 aşılma olasıllğı için elde edilen düşey eleman hasar verileri

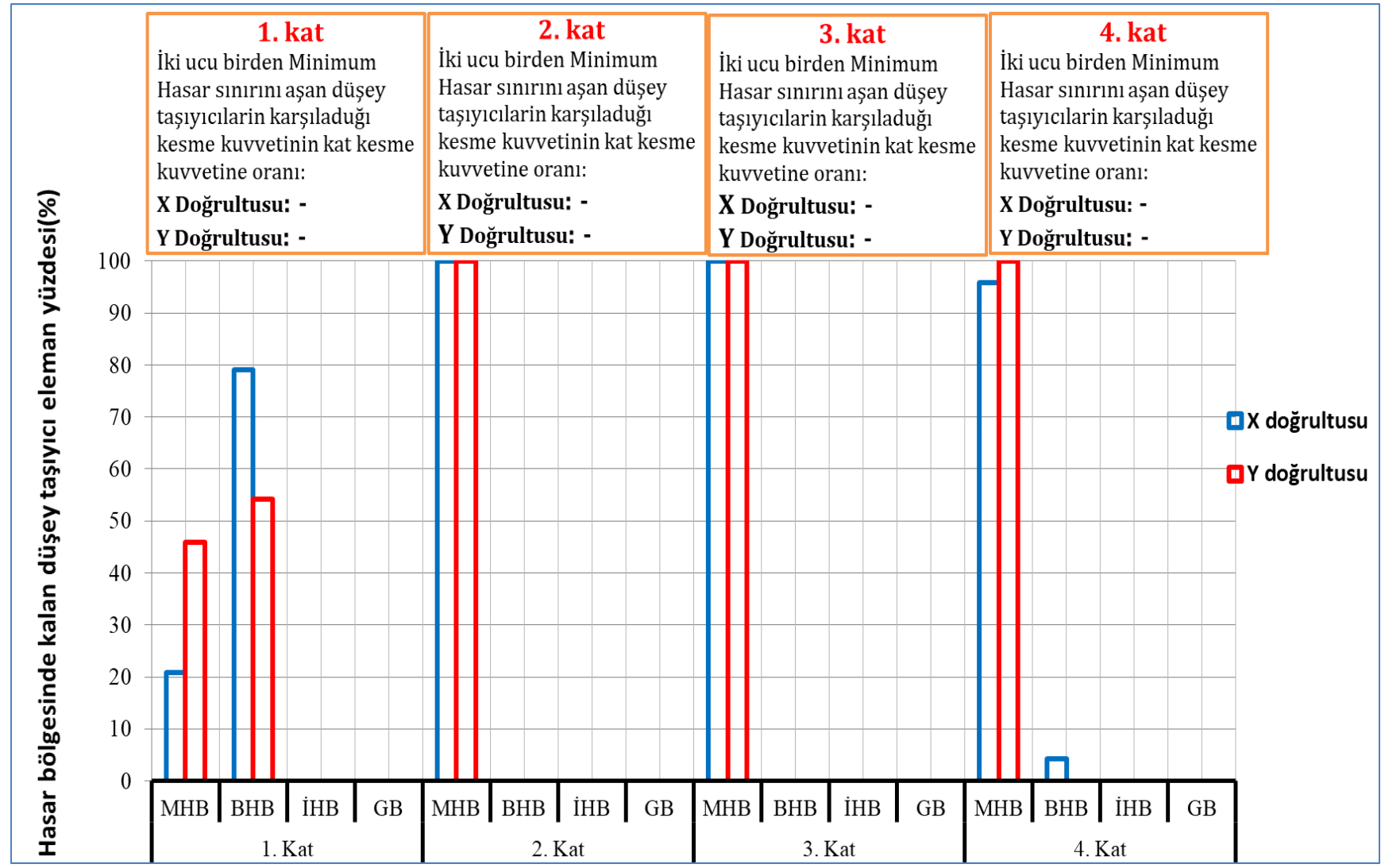

Şekil 12.b. DBYBHY 2007 [2]'e göre \%10 aşılma olasıllğ̆ için elde edilen düş̧ey eleman hasar verileri 


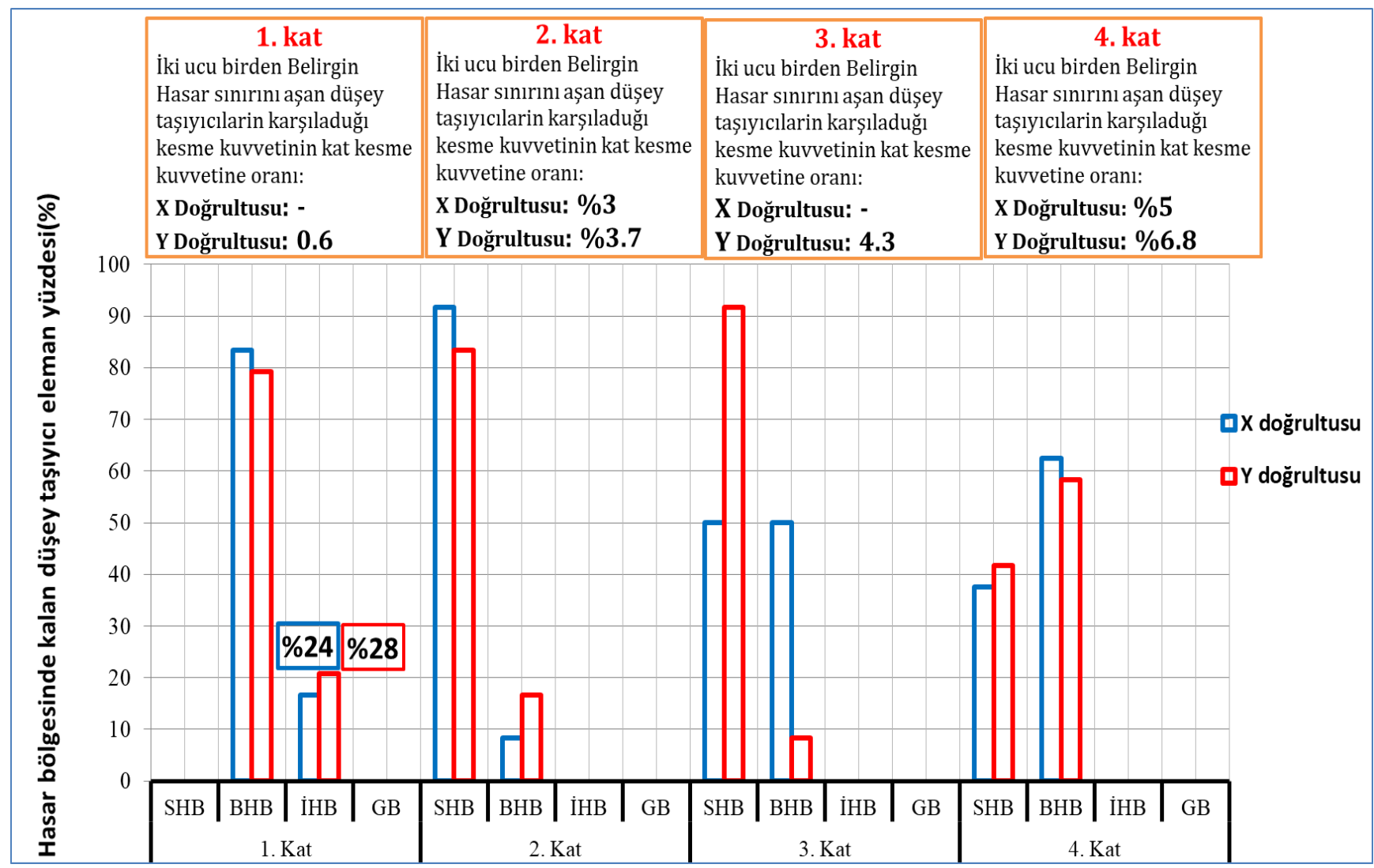

Şekil 12.c. TBDY 2018 [1]'e göre DD-1 için elde edilen düş̧ey taşıyıcı eleman hasar verileri

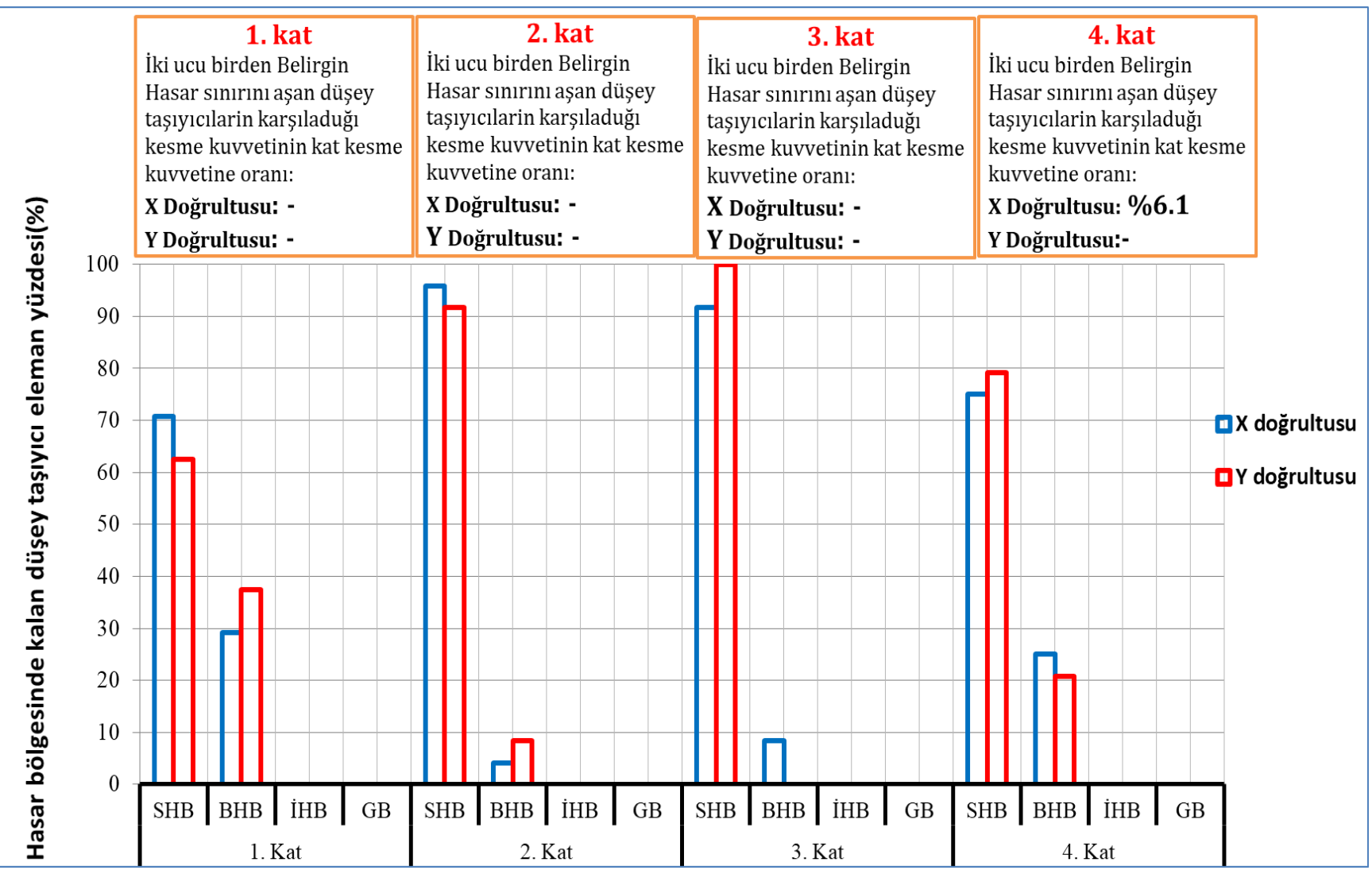

Şekil 12.d. TBDY 2018 [1]'e göre DD-3 için elde edilen düşey taşıyıcı eleman hasar verileri 
Şekil 12 ve Şekil 13 verileri Tablo 3 ve Tablo 4'te verilen koşullar ile kıyaslanmıştır. Böylece deprem yönetmeliği ve deprem düzeyine bağlı olarak performans seviyeleri elde edilmiştir. Elde edilen sonuçlar Tablo 5-8'de verilmiştir.

Tablo 5. DBYBHY 2007 [2]'e göre aşılma olasılı̆̆ $\% 2$ olan depremler için elde edilen performans seviyeleri

\begin{tabular}{|c|c|c|c|c|c|}
\hline \multirow{2}{*}{ Kat } & \multicolumn{2}{|c|}{$\begin{array}{c}\text { Kat performans } \\
\text { seviyesi }\end{array}$} & \multicolumn{2}{|c|}{ Doğrultu performans seviyesi } & $\begin{array}{c}\text { Bina } \\
\text { performans } \\
\text { seviyesi }\end{array}$ \\
\cline { 2 - 3 } & X yönü & Y yönü & X yönü & Y yönü & \multirow{2}{*}{ Gö } \\
\hline 1 & GÖ & CG & \multirow{2}{*}{ GÖ } & CG & GÖ \\
\hline 2 & CG & CG & & \\
\hline 3 & CG & CG & & & \\
\hline 4 & CG & CG & & &
\end{tabular}

Tablo 6. DBYBHY 2007 [2]'e göre aşılma olasıllı̆ $1 \% 10$ olan depremler için elde edilen performans seviyeleri

\begin{tabular}{|c|c|c|c|c|c|}
\hline \multirow{2}{*}{ Kat } & \multicolumn{2}{|c|}{$\begin{array}{c}\text { Kat performans } \\
\text { seviyesi }\end{array}$} & \multicolumn{2}{|c|}{ Doğrultu performans seviyesi } & $\begin{array}{c}\text { Bina } \\
\text { performans } \\
\text { seviyesi }\end{array}$ \\
\cline { 2 - 3 } & X yönü & Y yönü & X yönü & Y yönü & \multirow{2}{*}{ CG } \\
\hline 1 & CG & CG & & & CG \\
\hline 2 & CG & CG & \multirow{2}{*}{ CG } & CG & \\
\hline 3 & CG & CG & & & \\
\hline 4 & HK & CG & & & \\
\hline
\end{tabular}

Tablo 7. TBDY 2018 [1]'e göre DD-1 için elde edilen performans seviyeleri

\begin{tabular}{|c|c|c|c|c|c|}
\hline \multirow{2}{*}{ Kat } & \multicolumn{2}{|c|}{$\begin{array}{c}\text { Kat performans } \\
\text { seviyesi }\end{array}$} & \multicolumn{2}{|c|}{ Doğrultu performans seviyesi } & $\begin{array}{c}\text { Bina } \\
\text { performans } \\
\text { seviyesi }\end{array}$ \\
\cline { 2 - 3 } & X yönü & Y yönü & X yönü & Y yönü & \multirow{2}{*}{ Gö } \\
\hline 1 & GÖ & GÖ & \multirow{2}{*}{ GÖ } & GÖ \\
\hline 2 & KH & KH & \multirow{2}{*}{ GÖ } & & \\
\hline 3 & KH & KH & & & \\
\hline 4 & KH & KH & &
\end{tabular}

Tablo 8. TBDY 2018 [1]'e göre DD-3 için elde edilen performans seviyeleri

\begin{tabular}{|c|c|c|c|c|c|}
\hline \multirow{2}{*}{ Kat } & \multicolumn{2}{|c|}{$\begin{array}{c}\text { Kat performans } \\
\text { seviyesi }\end{array}$} & \multicolumn{2}{|c|}{ Doğrultu performans seviyesi } & $\begin{array}{c}\text { Bina } \\
\text { performans } \\
\text { seviyesi }\end{array}$ \\
\cline { 2 - 3 } & $\mathrm{X}$ yönü & Y yönü & X yönü & Y yönü & \multirow{2}{*}{ KH } \\
\hline 1 & $\mathrm{KH}$ & $\mathrm{KH}$ & & $\mathrm{KH}$ & $\mathrm{KH}$ \\
\hline 2 & $\mathrm{KH}$ & $\mathrm{KH}$ & \multirow{2}{*}{$\mathrm{KH}$} & & \\
\hline 3 & $\mathrm{KH}$ & $\mathrm{KH}$ & & & \\
\hline 4 & $\mathrm{KH}$ & $\mathrm{KH}$ & & &
\end{tabular}

\section{Sonuçlar}

Bu çalışmada, boyuna donatıları nervürsüz (düz) donatı çeliği ile düzenlenmiş mevcut okul türü bir binanın DBYBHY 2007 [2] ve TBDY 2018 [1] deprem yönetmeliklerinin her ikisine göre de deprem performansı belirlenmiş, Elde edilen bu sonuçlar kıyaslanmıştır. Yapılan performans değerlendirmelerinde aşağıdaki sonuçlar elde edilmiştir.

1) Binanın DBYBHY 2007 [2]'e göre performans değerlendirmesinde;

a) DBYBHY 2007 [2]'e göre mevcut okul türü bir binanın aşılma olasılığ $\% 2$ olan depremler için hedef performans seviyesi Can Güvenliği (CG)'dir. Tablo 9'dan da görüldüğü üzere aşılma olasılığı \%2 olan depremler için binanın $X$ Doğrultusu performans seviyesi Göçme Öncesi (GÖ), Y Doğrultusu performans seviyesi Can Güvenliği (CG) olarak elde edilmiştir. Dolayısı ile Y doğrultusu hedef performans seviyesini sağlıyor iken $\mathrm{X}$ doğrultusu hedef performans seviyesini sağlayamamaktadır. Binanın X doğrultusu 1. Kattaki kolon hasarlarından dolayı performans seviyesini sağlayamamaktadır.

b) DBYBHY 2007 [2]'e göre mevcut okul türü bir binanın aşılma olasılığ $\% 10$ olan depremler için hedef performans seviyesi Hemen Kullanım (HK)'dır. Tablo 10'dan da görüldüğü üzere aşılma olasılığ $\% 10$ olan depremler için binanın $\mathrm{X}$ ve $\mathrm{Y}$ doğrultularının performans seviyesi Can Güvenliği (CG) olarak elde edilmiştir. Dolayısı ile $X$ ve $Y$ doğrultularının her ikiside hedef performans seviyesini sağlayamamaktadır.

2) Binanın TBDY 2018 [1]'e göre performans değerlendirmesinde;

a) TBDY 2018 [1]'e göre mevcut okul türü bir binanın aşılma olasılı̆̆ $\% 2$ olan depremler (DD1) için hedef performans seviyesi Kontrollu Hasar (KH)'dır. Tablo 11'den de görüldügüü üzere aşılma olasılı̆̆ $1 \% 2$ olan depremler için binanın $\mathrm{X}$ ve $\mathrm{Y}$ doğrultularının performans seviyesi Göçmenin Önlenmesi (GÖ) olarak elde edilmiştir. Dolayısı ile X ve Y doğrultularının her ikiside hedef performans seviyesini sağlayamamaktadır. Binanın $X$ ve $Y$ doğrultularının ikiside 1. kattaki kolon hasarlarından dolayı performans seviyesini sağlayamamktadır.

b) TBDY 2018 [1]'e göre mevcut okul türü bir binanın DD-3 deprem düzeyi için hedef performans seviyesi Sinırlı Hasar (SH)'dır. Tablo 12'dan da görüldüğü üzere DD-3 deprem düzeyi için binanın X ve Y Doğrultularının performans seviyesi Kontrollü Hasar $(\mathrm{KH})$ olarak elde edilmiştir. Dolayısı ile X ve Y doğrultularının her ikiside hedef performans seviyesini sağlayamamaktadır.

3) İki yönetmeliğin performans sonucları kıyaslandığında yönetmelikler arasındaki uyumsuzluğun 50 yılda aşılma olasılığ $\% 2$ olan depremler için olduğu görülmektedir. 50 yılda aşılma olasılığı olasılığı \%2 olan depremler için binanın Y doğrultusu DBYBHY 2007 [2]'e göre hedef performans seviyesini sağliyor iken, TBDY 2018 [1]'e göre hedef performans seviyesini sağlayamaktadır.

4) Her iki aşılma olasılığı ve iki doğrultunun en elverişsiz olanı dikkate alındığında bina her iki yönetmeliğe göre de hedef performans seviyesini sağlamamıştır.

5) DBYBHY 2007 [2]'e göre yapılan çözümlerde 50 yılda aşılma olasılı̆̆1 \%2 olan depremler için $\mathrm{X}$ doğrultusunun hedef yerdeğiştirme istemi $190 \mathrm{~mm}, \mathrm{Y}$ doğrultusun hedef yerdeğiştirme istemi $181 \mathrm{~mm}$ olarak elde edilmiştir. TBDY 2018'e göre yapılan çözümlerde 
ise aynı deprem düzeyi için $\mathrm{X}$ doğrultusunun hedef yerdeğiştirme istemi $127 \mathrm{~mm}, \mathrm{Y}$ doğrultusun hedef yerdeğiştirme istemi $120 \mathrm{~mm}$ olarak elde edilmiştir. Buradan anlaşılacağı üzere binanın 2018 deprem yönetmeliğine göre elde edilen hedef yerdeğiştirme istemleri, 2007 deprem yönetmeliğine göre elde edilen değerden yaklaşık \%32 daha küçük çıkmıştır.

6) Bu çalışmada; donatı sınıfı S220, beton sınıfı C14 ve yeterli enine donatıya sahip olmayan mevcut okul türü bir binanın 2007 ve 2018 deprem yönetmeliklerine göre deprem performans sonuçları kıyaslanmıştır. İlerleyen çalışmalarda, boyuna donatıları nervürlü donatı çeliği ile düzenlenmiş, beton sınıfı daha yüksek, yeterli enine donatıya sahip olan ve kullanım amacı okul dışı olan binalar türleri için de benzer çalşmaların yapılması iki yönetmeliğin deprem perfomansı değerlendirmesi açısından kıyaslanması için faydalı olacağ düşünülmektedir.

\section{Çıkar çatışması}

Yazarlar çıkar çatışması olmadığını beyan etmektedir.

\section{Benzerlik oranı (iThenticate): \%19}

\section{Kaynaklar}

[1] TBDY, Türkiye Bina Deprem Yönetmeliği, Afet ve Acil Durum Yönetimi Başkanlığı, Ankara, 2018.

[2] DBYBHY, Deprem Bölgelerinde Yapılacak Binalar Hakkında Yönetmelik, T. C. Çevre ve Şehircilik Bakanlığı, Ankara, 2007.

[3] H. Karaca, S. P. Oral, M. Erbil, Yapisal tasarım bağlamında 2007 ve 2019 deprem yönetmeliklerinin karşılaştırılması, Niğde örneği. Niğde Ömer Halisdemir Üniversitesi Mühendislik Bilimleri Dergisi, $9(2) \quad, \quad 898-903,2020 . \quad$ https://doi.org/ 10.28948/ngumuh. 667365

[4] M. H. Severcan, B. Sinanı, Mevcut betonarme yapıların deprem performansının analizi. Niğde Ömer Halisdemir Üniversitesi Mühendislik Bilimleri Dergisi, 8(2), 936-947, 2019. https://10.28948 /ngumuh.598151

[5] EUROCODE 8, Design of Structures for Earthquake Resistance Part 3: Assessment and Retrofitting of Buildings, Doc. CEN/TC250/SC8/N388B. Comité Européen de Normalisation, Bruxelles, 2004
[6] H. Ulutas, DBYBHY (2007) ve TBDY (2018) deprem yönetmeliklerinin kesit hasar sınırları açısından k1yaslanması. Avrupa Bilim ve Teknoloji Dergisi, (17), 351-359, 2019. https://10.31590/ejosat.620827

[7] İ. Ünsal, F. A. Öncel, TDY 2007 ve TBDY 2018 yönetmeliklerine göre yapı yüksekliğinin taban kesme kuvveti ve tepe deplasmanı üzerindeki etkisinin incelenmesi. Konya Mühendislik Bilimleri Dergisi, 8(4), 930-942, 2020. https://10.36306/konjes.752139

[8] İ. Dalyan, B. Şahin, Mevcut Betonarme Bir Binanın 2007 ve 2018 Deprem Yönetmeliklerine Göre Deprem Yükleri Altındaki Taşıyıcı Sistem Performansının Değerlendirilmesi. Türk Deprem Araştırma Dergisi, 1 (2), 134-147, 2019.

[9] O. Sar1, Mevcut konut türü bir binanın DBYBHY-2007 ve TBDY-2018 deprem yönetmeliklerine göre deprem performansının değerlendirilmesi. Yüksek Lisans Tezi, Burdur Mehmet Akif Ersoy Üniversitesi Fen Bilimleri Enstitüsü, Türkiye, 2020.

[10] U. Ayaz, Mevcut bir betonarme binanın 2007 ve 2018 Türkiye bina deprem yönetmeliklerine göre deprem performansının değerlendirilmesi ve güçlendirilmesi. Yüksek Lisans Tezi, Gebze Teknik Üniversitesi Fen Bilimleri Enstitüsü, Türkiye, 2020.

[11] O. Eldemir, DBYBHY-2007 ve TBDY-2018 yönetmeliklerinin mevcut yapıların sismik davranış özellikleri açısından karşılaştırılması. Pamukkale Üniversitesi Fen Bilimleri Enstitüsü, Türkiye, 2019

[12] Ö. F. Nemutlu, 2007-2018 Türk deprem yönetmeliklerinin ve Amerikan deprem yönetmeliğinin deprem hesapları açısından karşılaştırılması. İstanbul Teknik Üniversitesi Fen Bilimleri Enstitüsü, Türkiye, 2019

[13] ASCE 7-16, American Society of Civil Engineers, Minimum Design Loads and Associated Criteria for Buildings and Other Structures, , 2017.

[14] H. Elçi, K. A. Goker, Deprem yönetmeliklerinin (DBYBHY 2007 ve TBDY 2018) betonarme kolonların deprem performansı açısından karşılaştırılması. International Journal of Scientific and Technological Research, 4(6), 9-21, 2018.

[15] SAP2000 V.21, Computers and Structures, Inc., http://www.csiberkeley.com, 1995 University Avenue Berkeley, California 94704 USA,. 1978-2020. 